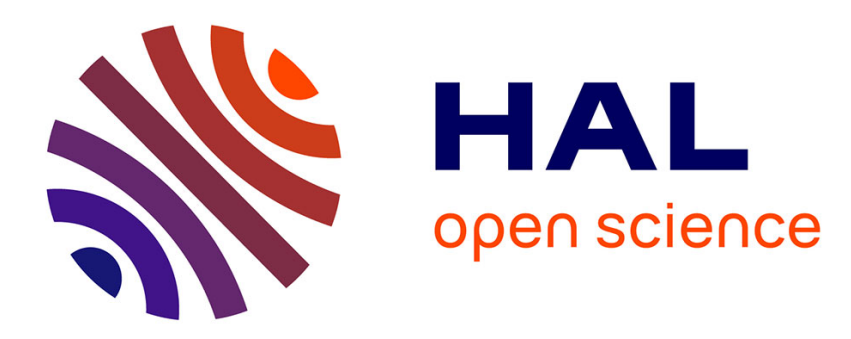

\title{
Entry and Market Selection of Firms: A Laboratory Study
}

Jordi Brandts, Ayça Ebru Giritligil

\section{To cite this version:}

Jordi Brandts, Ayça Ebru Giritligil. Entry and Market Selection of Firms: A Laboratory Study. Journal of Economic Behavior and Organization, 2008, 68 (3-4), pp.593. 10.1016/j.jebo.2008.06.012 . hal-00643021

\section{HAL Id: hal-00643021 \\ https://hal.science/hal-00643021}

Submitted on 21 Nov 2011

HAL is a multi-disciplinary open access archive for the deposit and dissemination of scientific research documents, whether they are published or not. The documents may come from teaching and research institutions in France or abroad, or from public or private research centers.
L'archive ouverte pluridisciplinaire HAL, est destinée au dépôt et à la diffusion de documents scientifiques de niveau recherche, publiés ou non, émanant des établissements d'enseignement et de recherche français ou étrangers, des laboratoires publics ou privés. 


\section{Accepted Manuscript}

Title: Entry and Market Selection of Firms: A Laboratory Study

Authors: Jordi Brandts, Ayça Ebru Giritligil

PII: $\quad$ S0167-2681(08)00137-6

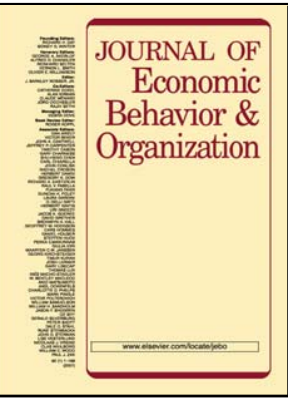

DOI: $\quad$ doi:10.1016/j.jebo.2008.06.012

Reference: $\quad$ JEBO 2234

To appear in: Journal of Economic Behavior \& Organization

Received date: $\quad 19-1-2007$

Revised date: $\quad 25-6-2008$

Accepted date: $\quad 29-6-2008$

Please cite this article as: Brandts, J., Giritligil, A.E., Entry and Market Selection of Firms: A Laboratory Study, Journal of Economic Behavior and Organization (2007), doi:10.1016/j.jebo.2008.06.012

This is a PDF file of an unedited manuscript that has been accepted for publication. As a service to our customers we are providing this early version of the manuscript. The manuscript will undergo copyediting, typesetting, and review of the resulting proof before it is published in its final form. Please note that during the production process errors may be discovered which could affect the content, and all legal disclaimers that apply to the journal pertain. 


\title{
Entry and Market Selection of Firms: A Laboratory Study
}

\author{
by Jordi Brandts and Ayça Ebru Giritligil \\ Institut d'Anàlisi Econòmica (CSIC), Barcelona.
}

June 2008

\begin{abstract}
We study how markets adjust to the entry of new firms under different conditions. Two incumbents face entry by three other firms. When firms' costs are equal, entry always leads consumer surplus and profits to their equilibrium levels. When entrants are more efficient than incumbents, entry leads consumer surplus to equilibrium. With cost asymmetries, market behavior is satisfactory from the consumers' standpoint but does not yield adequate signals to other potential entrants. Simultaneous entry is in the short run more favorable to consumers than sequential entry. A longer incumbency phase favors consumers after entry.
\end{abstract}

Keywords:

Market selection, Imperfect competititon, Entry, Experiments

\section{JEL Classification Codes:}

C09, C72, D43, D83, L13

\section{Acknowledgements}

Financial support from the Ministerio de Educación, Cultura y Deporte and the Barcelona Economics programme CREA is gratefully acknowledged. The authors thank Ágnes Pintér for programming the experiment and David Rodríguez for organizing and running the experiments. The authors are grateful to the members of the Leex, Universitat Pompeu Fabra, for letting us use their lab facilities and their student volunteers data base.

* Institut d'Anàlisi Econòmica (CSIC), Campus UAB, 08193 Bellaterra, Spain, Phone +34-93-5806612 Fax +34-93-5801452, Brandts: jordi.brandts@uab.es, Giritligil: ayça.ebru@uab.es 


\section{Introduction}

For markets to function well they need to react properly to new entrants. Newcomers have to be able to capture a part of the market, and more efficient entrants have to succeed in displacing, partially or completely, older less efficient firms. This process of readjustment and renewal is at the core of the creative destruction that is crucial to the progress of modern societies. Following Schumpeter, economists have devoted considerable attention to analyzing this process, as in the work of Jovanovic (1982), Hopenhayn (1992), Ericson and Pakes (1995), Roberts and Tybout (1997) and Caves (1998).

In this paper, we present results from experiments designed to shed light on some particular aspects of the process of entry and exit. More specifically, we study how markets in which incumbent firms face entry by other firms adjust to the new competition. We are interested in seeing whether there is a pure incumbency or firstmover effect, in the sense that the very fact that some firms have been present in a market earlier than others gives them an advantage over the latecomers. In the cases we will be studying, incumbents will not have the possibility of preventing entry by precommiting to appropriate output levels, as in the literature that starts with Bain (1956) and Sylos-Labini (1962). There will be no entry cost. What we ask is whether incumbency itself creates an asymmetry that favors established firms and allows them to hold on to their position in the market.

Our central interest is in the study of efficiency in our markets. We ask both whether the market prices that emerge are satisfactory from the consumers' standpoint and whether more efficient entrants are able to displace the less efficient established firms, so that the market gives the appropriate signals to other potential entrants. In the environments we study there is an avoidable fixed cost so that, depending on the overall cost distributions, the market may not be able to accommodate all the firms that would like to be present in it. In our experiments we are able to study this accomodation process in detail. Specifically, we study how the length of time in which incumbents are protected from competition, the cost advantages of entrants, and the time-structure of the entry-process affect firm behavior and market efficiency. The impact of these three factors yields a broad picture of the entry process.

Issues related to the ones we study here have been analyzed before. The strategy and marketing literature has paid considerable attention to the analysis of first-mover 
advantages. The seminal article is Lieberman and Montgomery (1988). More recently the articles by Kerin et al. (1992), Robinson et al. (1994), Zahra et al. (1995), Mueller (1997) and Lieberman and Montgomery (1998) have surveyed and classified the contributions to this literature. These studies use field data to analyze the extent to which first-mover advantage exists in different industries and proposes that firms that enter the market early may be able to obtain advantages of various types such as prime physical locations or favourable customer perception.

The theoretical industrial organization literature has carefully studied the strategic aspects of incumbency advantages. The issue of entry deterrence by established firms has received considerable attention as one of the leading instances of the importance of commitment in sequential games. References to and discussions of these issues appear in virtually all the teaching manuals in the area (see e.g. Tirole 1989, Basu 1993, Martin 1993 and Vives 1999).

In this paper we approach things from a different perspective. We ask whether markets exhibit inertia of a non-strategic type. The existence of inertia is often considered in economic analysis, as when hysteresis is taken into account in macroeconomics. Adjustment to new market circumstances often just takes time, and during this transition those firms that were in the market first may enjoy a better situation than in the long run. This kind of inertia can then be a relevant factor intervening in the entry process of new firms into a market and have considerable efficiency consequences.

Some previous experimental studies have found evidence of a purely nonstrategic advantage of incumbents. Brandts et al. (2007) find evidence of first-mover advantage in an experimental study of how incumbents can use investment in capacity to deter entry, in which the strategic prediction is that of second-mover advantage. There are also several studies on the topic of order of play in experimental games. Rapaport et al. (1990), Rapaport et al. (1993), and Rapaport (1997) find evidence that in bargaining games and sequential common resource dilemmas, earlier movers take larger portions than do late movers. Weber et al. (2004) and Muller and Sadanand (2003) find that when simple two-person games that are simultaneous in terms of information are played sequentially, the first mover tends to do better than when both players make actual simultaneous choices. In the present paper we ask whether this kind of phenomenon also emerges in a market selection environment. 
The study by Huck et al. (2007) on the merger paradox contains a thorough experimental analysis of the effects the merging of firms has on market shares and competition under quantity competition; of special interest is how the authors relate their work to field-data studies on mergers. The paper also contains an experimental treatment on entry which is related to our work. In our concluding section we will come back to this study and discuss the connections between their work and ours.

Experiments have been used to study a large number of policy-relevant market and industrial organization issues. The focus of these studies is on the interaction of firms in a variety of environments. Isaac and Smith (1985) and Jung et al. (1994) study the workings of predatory pricing, and Huck et al. (2000) study effects on firm behavior of providing firm-specific price and profit data. A number of studies such as Rassenti et al. (2001, 2002, and 2003), Abbink et al. (2003), and Brandts et al. (2008) analyze aspects of market power in electricity markets. Plott (1997) and Plott and Salmon (2004) discuss the use of experiments in relation to the spectrum auctions in the US. Holt (1995) surveys some of the earlier literature on industrial organization experiments, and Normann (2006) present a more specific recent overview and discussion of the use of experiments for antitrust policy. As in other areas the advantage of experimental studies of firm interaction are replicability and control. With respect to our experiments, we think that it will be clear below that it would have been difficult to carry out our analysis on the basis of field data alone, since in natural environments it would be unusual to find appropriate data with the desired variations in the cost structures, the nature of the entry process, and the length of the incumbency period.

We base our analysis on the case of quantity competition. This way of modeling the interaction between firms has been used in numerous empirical studies involving field data. For example, Bresnahan and Reiss (1991) refer to quantity competition in their empirical study of entry and competition in concentrated markets, and Borenstein and Bushnell (1999) study markets in the California electricity market after deregulation and represent it as a Cournot market with a competitive fringe. The frequent use of the Cournot model in applied work suggests that this is a sensible way of representing in a simplified manner the workings of certain markets.

One important characteristic of experimental studies of market interaction is that equilibrium behavior is not imposed. Participants in the experiment know the market rules and in our case act under complete information, but there is no reason to expect 
(nor to impose) that they will from the start jump to the corresponding market equilibrium. Rather, they will make some reasonable initial decision and then react to the actions of others and to what they learn about the market environment they are in. This process may then lead to equilibrium or not. We believe that the lack of imposition of equilibrium behavior is an advantage of the experimental approach since it corresponds better to how firms have to find their way in the market. As will be seen below, actual behavior will overall be influenced by the most relevant equilibrium. However, the process of adjustment takes time and has some important qualitative features.

Our results show that when incumbents and entrants have identical costs, sufficient entry drives consumer surplus and profits to their equilibrium levels. In contrast, when entrants are more efficient than incumbents, entry leads consumer surplus to equilibrium, but total profits remain substantially below equilibrium since incumbents are able to keep market shares significantly above what equilibrium prescribes. This is possible due to the willingness to accept negative profits for a good number of market rounds. Efficient entrants produce too little and earn too little. Market perfomance is satisfactory from the consumers' standpoint (total production is high enough) but entrants' low profits do not yield adequate signals to other potential entrants. These results are not affected by whether entry is simultaneous or sequential, whereas the length of the incumbency phase does have some secondary effects.

\section{Experimental design}

All our experimental sessions start with two identical incumbents competing in quantities for a fixed number of periods. ${ }^{1}$ After these periods additional firms are given access to the market. We report data from a total of six treatments, summarized in Table 1.

\footnotetext{
1 We could have started with a monopolist incumbent. However, the two incumbent case yields information concerning cooperation of settled firms. As shown by Huck et al. (2004) collusion is not easily sustained with three or more firms.
} 


\begin{tabular}{||c|c|c|c||}
\hline \multicolumn{4}{|c|}{ TABLE 1. SUMMARY OF TREATMENTS } \\
\hline Treatment label & Timing of entry & Cost distribution & Incumbency duration \\
\hline Seq-Sym10 & Sequential & $\begin{array}{c}5 \text { firms with identical } \\
\text { marginal and fixed } \\
\text { costs }\end{array}$ & 10 rounds \\
\hline Simul-Sym10 & Simultaneous & Same as Seq-Sym10 & 10 rounds \\
\hline Seq-Asym10 & Sequential & $\begin{array}{c}\text { 2 identical incumbents } \\
\text { with higher marginal } \\
\text { costs than the three } \\
\text { identical entrants and } \\
\text { identical fixed costs }\end{array}$ & 10 rounds \\
\hline Simul-Asym10 & Simultaneous & Same as Seq-Asym10 & 10 rounds \\
\hline Seq-Asym20 & Sequential & Same as Seq-Asym10 & 20 rounds \\
\hline Simul-Asym20 & Simultaneous & Same as Seq-Asym10 & 20 rounds \\
\hline
\end{tabular}

We study the effects of three treatment variables: the timing of entry, the distribution of firms' costs, and the duration of incumbency. The variation in these variables is meant to get at some of the potentially crucial aspects of the process of firms entering the market and the market selecting market shares for the different firms. The difference between sequential and simultaneous entry is the following. Under sequential entry one of the entrants is given access to the market in the first period after incumbency is over, a second firm 10 periods later, and a third firm after another 10 periods. Under simultaneous entry all entrants are given access to the market in the first period after incumbency is over.

The variation in the length of the incumbency period is motivated by our interest in inertia; a longer incumbency period can potentially lead to more inertia. Our distinction between symmetric and asymmetric cost structures is precisely directed at discovering (by comparison) in which way the presence of asymmetric firms affects behaviour. The distinction between sequential and simultaneous entry is meant to reflect the situations in different types of markets. For example, in some newly deregulated markets, entry takes place sequentially. ${ }^{2}$

\subsection{Theoretical Background and Research Questions}

What are the available theoretical benchmarks for the treatments? From previous experimental work by Huck et al. (2004), we know that behaviour in repeated quantity competition games can be expected to conform to the equilibria of the corresponding 
one-shot game, even if the interaction takes place over 50 rounds or more. Therefore, Table 2 presents the relevant complete information Cournot equilibria for the specific parameter configurations we used as our benchmarks.

\begin{tabular}{|c|c|c|c|c|}
\hline \multicolumn{5}{|c|}{ TABLE 2. COURNOT EQUILIBRIUM BENCHMARKS* } \\
\hline Treatment & $\begin{array}{l}\text { Demand } \\
\text { function }\end{array}$ & $\begin{array}{l}\text { Fixed and } \\
\text { Variable Costs }\end{array}$ & Equilibrium quantities & $\begin{array}{l}\underline{\text { Equilibrium }} \\
\text { total surplus }\end{array}$ \\
\hline Seq-Sym10 & $\mathrm{P}=13-0.2 \mathrm{Q}$ & $\begin{array}{l}\mathrm{FC}=15 \\
\mathrm{IMC}=1 \\
\mathrm{EMC}=1\end{array}$ & $\begin{array}{l}\text { Rounds 1-10: } \mathrm{IQ}=20 \\
\text { Rounds 11-20: } \\
\mathrm{IQ}=\mathrm{EQ}=15 \\
\text { Rounds } 21-30: \\
\mathrm{IQ}=\mathrm{EQ}=12 \\
\text { Rounds } 31-40: \\
\mathrm{IQ}=\mathrm{EQ}=10\end{array}$ & $\begin{array}{c}\text { Rounds 1-10: } \\
290 \\
\text { Rounds 11-20: } \\
292.5 \\
\text { Rounds 21-30: } \\
285.6 \\
\text { Rounds 31-40: } \\
275\end{array}$ \\
\hline Simul-Sym10 & $\mathrm{P}=13-0.2 \mathrm{Q}$ & $\begin{array}{l}\mathrm{FC}=15 \\
\mathrm{IMC}=1 \\
\mathrm{EMC}=1\end{array}$ & $\begin{array}{c}\text { Rounds 1-10: } \mathrm{IQ}=20 \\
\text { Rounds } 11-40: \\
\mathrm{IQ}=\mathrm{EQ}=10\end{array}$ & $\begin{array}{c}\text { Rounds 1-10: } \\
290 \\
\text { Rounds 11-40: } \\
275 \\
\end{array}$ \\
\hline Seq-Asym 10 & $\mathrm{P}=11-0.1 \mathrm{Q}$ & $\begin{array}{l}\mathrm{FC}=30 \\
\mathrm{IMC}=2 \\
\mathrm{EMC}=1\end{array}$ & $\begin{array}{l}\text { Rounds 1-10: IQ=30 } \\
\text { Rounds 11-20: } I Q=20 \text {, } \\
E Q=30 \\
\text { Rounds } 21-30: I Q=0 \\
E Q=33 \\
\text { Rounds } 31-40: I Q=0, \\
E Q=25\end{array}$ & $\begin{array}{c}\text { Rounds 1-10: } \\
300 \\
\text { Rounds 11-20: } \\
325 \\
\text { Rounds 21-30: } \\
383.1 \\
\text { Rounds 31-40: } \\
378.75\end{array}$ \\
\hline Simul-Asym10 & $P=11-0.1 Q$ & $\begin{array}{l}\mathrm{FC}=30 \\
\mathrm{IMC}=2 \\
\mathrm{EMC}=1\end{array}$ & $\begin{array}{l}\text { Rounds 1-10: } \mathrm{IQ}=30 \\
\text { Rounds 11-40: } \mathrm{EQ}=25\end{array}$ & $\begin{array}{c}\text { Rounds 1-10: } \\
300 \\
\text { Rounds 31-40: } \\
378.75 \\
\end{array}$ \\
\hline Seq-Asym20 & $\mathrm{P}=11-0.1 \mathrm{Q}$ & $\begin{array}{l}\mathrm{FC}=30 \\
\mathrm{IMC}=2 \\
\mathrm{EMC}=1\end{array}$ & Same as Seq-Asym10 & $\begin{array}{l}\text { Analogous to } \\
\text { Seq-Asym } 10\end{array}$ \\
\hline Simul-Asym 20 & $\mathrm{P}=11-0.1 \mathrm{Q}$ & $\begin{array}{l}\mathrm{FC}=30 \\
\mathrm{IMC}=2 \\
\mathrm{EMC}=1\end{array}$ & Same as Simul-Asym10 & $\begin{array}{c}\text { Analogous to } \\
\text { Simul-Asym } 10\end{array}$ \\
\hline
\end{tabular}

* P stands for the market price, Q for total quantity, FC for fixed cost, IMC for incumbent marginal cost, $\mathrm{EMC}$ for entrant marginal cost, IQ for incumbent quantity, and EQ for entrant quantity. The collusive quantity is 50 when $\mathrm{MC}=1$ and 30 when $\mathrm{MC}=2$

As can be seen from the table the demand function was always linear and the fixed cost was always the same for all firms in a treatment but with small variations across treatments because we wanted equilibrium quantity choices to be integers for implementation in the experiment. In the two variations of treatment 1 , the five firms

\footnotetext{
${ }^{2}$ The theoretical IO literature also distinguishes between simultaneous and sequential entry. See Vives.
} 
were identical. In all the variations of treatment 2 , all three identical entrants have a marginal cost that is half the one of incumbents. ${ }^{3}$

The fourth column of Table 2 shows the equilibrium predictions corresponding to the Cournot equilibrium. ${ }^{4}$ For treatments Seq-Sym10 and Simul-Sym10 the equilibrium pattern is very straightforward: individual output is always positive and decreases with the number of firms in the market, while total output increases with this number. For the other four treatments the equilibrium patterns are more interesting. In rounds 11-20 of Seq-Asym10 (21-30 in treatment Seq-Asym20) the first of the entrants simply obtains a larger market share than each of the incumbents, but once the second entrant has access to the market, the two incumbents leave the market, due to the existence of the avoidable fixed cost. In the two treatments with asymmetric firms and simultaneous entry the three entrants expel the incumbents from the market right away. This kind of "dynamics" in which more efficient firms replace less efficient firms over time is what we are interested in exploring. ${ }^{5}$ In natural markets, there are certainly many instances where some established firms have to stop producing altogether due to the productive superiority of new entrants. ${ }^{6}$

Our most general interest is in seeing how well these markets perform after entry takes place, both with respect to consumers and to producers. What are the research questions about firm behaviour for the first two treatments: Seq-Sym10 and SimulSym10? ${ }^{7}$ Given that firms are identical, equilibrium production levels are of course identical. However, perhaps incumbents will, after entry, somehow be able to keep a larger part of the market. The simple fact of being in the market first may give them an advantage in the eyes of the entrants. What is important here is that if incumbents

\footnotetext{
${ }^{3}$ We feel that this is a natural way to start. Other patterns of heterogeneous costs will be studied in future work.

${ }^{4}$ The production level that is shown always corresponds to that of the firms that have access to the market in the corresponding periods.

${ }^{5}$ For the dynamics one important issue is the chosen time horizon. For the experiments we present in this paper we chose 40 and 50 periods. A substantially longer horizon may change behavior. Additionally, to get closer to an infinite horizon environment, it would be possible to implement a situation with random termination or even one in which termination would be certain but unknown to participants.

${ }^{6}$ A possible drawback of a design in which some firms produce zero in the post-entry equilibrium is that errors and being bored with doing nothing could lead participants to produce a non-equilibrium quantity. However, we feel that as a first step, it is good to study the case that more directly represents some important situations in the field.

${ }^{7}$ Observe that our experiments are not intended simply to look at comparative statics. Rather, our design focuses on history of dependence and change.
} 
produce more than the equilibrium prescribes, then the entrants' best responses imply that they yield some market share to the incumbents.

The notion that we posit here is related to some intuitive ideas and to some evidence about the existence of a perceived first-mover advantage, mentioned in the introduction. The notion of aspiration levels is important here. Huck et al. (2007) show that their results about the merger paradox can be explained by aspiration levels, which in this context refer to firms' commitment to maintaining their original profits. They extensively discuss field-data studies in which aspiration levels are part of the explanation of merger behavior. We refer the reader to that discussion, which highlights the connection between research with experimental and with field data.

Another conjecture pertains to possibly different effects of sequential vs. simultaneous entry. From Huck et al. (2004) we know that repeated quantity competition with two firms leads to some collusion, while with three and four firms the Cournot stage-game equilibrium is a good predictor. However, this regularity was observed for the case where all firms are in the market from the start. For our cases, behaviour may be different. In particular for treatment Seq-Sim10 with sequential entry, one can conjecture that the expected initial collusion of the incumbents will rather easily carry over to subsequent rounds; the fact that the number of firms increases gradually may make it possible to maintain some degree of collusion with more than two firms.

In contrast, for treatment Simul-Sym10 it seems a priori less likely that collusion will survive after round 11 since three firms will enter simultaneously and the market will then instantly have five firms, a number for which previous evidence suggests production levels close or even above the Cournot stage-game equilibrium.

For the comparison between symmetric and asymmetric treatments, it is less straightforward to formulate plausible a priori conjectures. The fact that incumbents are less efficient than entrants may cause them to yield more easily; the cost difference may make the option of giving in to the entrants more salient. However, at the same time incumbents may feel more motivated to resist the equilibrium forces, since they lead to incumbents' complete defeat. If entrants anticipated such a resistance, then they may behave more conservatively and hence leave some share of the market for the incumbents. Before the fact both these possibilities make some sense.

With respect to the asymmetric treatments, another question is how the interaction between inefficient incumbents and efficient entrants will depend on whether 
entry is sequential or simultaneous. Here our intuition is, as for the case of identical firms, that sequential entry will be more favorable to incumbents' resistance to change.

For the comparison between treatments Seq-Asym10 and Seq-Asym20 on one side and treatments Simul-Asym10 and Simul-Asym20 on the other side simple intuition suggests that longer incumbency duration may lead to better collusion after entry occurs. Inertia may be a force in our context. ${ }^{8}$

We can now succinctly state our four research questions:

1. Will consumer surplus and total profits after entry be at equilibrium levels and, if there are significant deviations, how do they depend on the treatment variables?

2. Can incumbents ensure themselves a larger than equilibrium market share after entry has occurred and how does this depend on whether incumbents are efficient or inefficient?

3. Do the answers to questions 1 and 2 depend on whether entry is sequential or simultaneous?

4. Do the answers to questions 1 and 2 depend on the length of the incumbency phase?

\subsection{Procedures}

The experiment was programmed using z-tree (see Fischbacher 2007), and the sessions were run in the experimental laboratories of the UAB and the UPF. The experimental participants were UAB and UPF students from a variety of fields of study. Each person was allowed in only one session. The appendix (available on the JEBO website) contains a translation of the instructions for treatment 2.1a. In all our experiments subjects had the roles of the different firms, while the demand was simulated (see the instructions). Subjects had complete information about the parameter configuration of the group they were in. However, they had no information about equilibrium quantities.

Subjects interacted in fixed groups of five over the 40 or 50 rounds to reflect the repeated game character of actual oligopoly markets. Two or three groups were

\footnotetext{
${ }^{8}$ For an experimental analysis of inertia in the context of how to turn around organizations that are suffering from coordination failure, see Brandts and Cooper (2006).
} 
simultaneously in the lab. Subjects were not told which of the other session participants were in the same group.

\section{Results}

We start by a general description of our data. Table 3 contains period-per-period actual and equilibrium quantities for all six treatments, aggregated over groups of each treatments. Table 4 shows analogous information for actual and equilibrium total surplus levels. We have data from nine independent groups (markets) for the six treatments shown in Table 1. In section 3.2 we present a more formal statistical analysis of our results.

\subsection{Overview}

We start with treatment Seq-Sym10. The average total quantity data shown in Table 3 indicate that tacit collusion is substantial with two firms, persists with three and four firms, and only diminishes with five firms. ${ }^{9}$ Figure 1 shows firms' average production levels dependent on when they are given access to the market. After entry incumbents' average production levels are not larger than those of the relevant entrants; indeed, after round 21 incumbents' production levels are mostly below those of the other firms.

The data shown in Tables 3 and 4 for the Simul-Sym10 treatment outcomes are qualitatively similar to those of the Seq-Sym 10 treatment. Considerable tacit collusion appears in the incumbency phase and a weak degree of it after entry. Consistent with this, entry leads to total surplus levels close but below equilibrium ones. Now entry does lead to production levels close to the Cournot equilibrium. Figure 2 reveals that entry and incumbents produce similar amounts. Together, figures 1 and 2 document that in our two symmetric treatments, incumbents do not resist entry.

Behaviour for the Seq-Asym10 treatment is shown in Figures 3, 4, and 5 and in the corresponding columns of Tables 3 and 4. Total production over time indicates, as before, collusion in the first ten rounds and in rounds 21 to 30 ; observe that for rounds 1-20 all total average production levels are above the corresponding equilibrium levels. In subsequent periods, output levels reach and often "overshoot" the equilibrium levels,

\footnotetext{
${ }^{9}$ Average total production in the first 10 rounds is 30,25 , and in none of the rounds is it above the equilibrium of 40 .
} 
something that was rare for the case of identical firms. Figure 3 shows the average behavior of the different firms that enter at different points in time, and figure 4 shows average behavior of the inefficient incumbents and average behaviour (irrespective of entry time) of the more efficient entrants, together with the Cournot equilibrium levels. Incumbents' total quantity does decrease over time, but much more slowly than what the equilibrium levels prescribe. Consistent with this, entrants produce considerably less than in equilibrium. Figure 5 shows average profits of the two types of firms. Here one can see that incumbents' profits become negative in the last part of the experiment, and one may conjecture that, with a longer time-horizon, this would lead to the complete exit of incumbents.

The comparison of total surplus with equilibrium total surplus in Table 4 reveals that the markets of treatment Seq-Asym10 are under-performing over the complete time-horizon. The under-performance of the first ten periods is similar to what we saw for the case of identical firms. However, what happens in periods 11 to 40 is different from the identical firm case for two reasons. First, for periods 21 to 40 the difference between behavior and equilibrium is larger than in treatment Seq-Sym10. Second, we know from Table 3 that the total quantity produced is not inefficient. The problem is, as indicated by the graphs in figure 4, that the output level is produced in an inefficient way. The market has difficulty in selecting the right firms to produce the right levels of quantities, at least in the time-horizon that we consider. In comparison with the identical firms case, behavior in this treatment is more favorable to the consumer but not so in terms of the use of production resources. Market signals to possible additional entrants are not the right ones.

For treatment Simul-Asym10 the data in Table 3 reveal that for the total quantity there are no clear differences with respect to the behavior of the previous treatment. ${ }^{10}$ Figures 6 to 7 show output decisions in the treatment at a more disaggregated level. Figure 6 shows average production levels of the two types of firms, as well as the corresponding equilibrium levels. Apart from the post-entry drop, we do not observe any clear time trend of incumbents' output levels. Entrants' average production levels do not exhibit any clear trend either. In the final rounds, incumbents appear to produce a bit more and entrants a bit less than in equilibrium. Figure 7 shows average profits per type of player. The fact that incumbents' average profits are negative in almost all post-

${ }^{10}$ In rounds 11-20 firms appear to be colluding a bit more for the case of sequential entry than for simultaneous entry. 
entry periods is surprising. The data in Table 4 show again under-performance of the market over all 40 rounds. As before, equilibrium consumer surplus is attained; the root of the considerable inefficiency is the allocation of production to the two types of firms.

Are things different when incumbents are sheltered from entry for a longer time? Figures 8 to 10 depict behavior in treatment Seq-Asym20. Comparing in Table 3 the evolution of quantity to that for the Seq-Asym10 treatment, the apparent differences are not very striking. For rounds 11 to 20 involving a triopoly, quantities appear to be a bit lower in treatment Seq-Asym 20, but the differences are really minor. Similarly, the comparison of average production levels (figures 9 vs. 4), profits (figures 10 vs. 5), and surplus levels (Table 4) do not reveal any relevant differences. To complete our first look at behavior in the different treatments, figures 11 and 12 pertaining to treatment Simul-Asym 20 document that for the case of block entry, the length of the incumbency has no effect on behavior.

Figure 13 presents the ratios of total profits over equilibrium profits for the six treatments and the four blocks of rounds and figure 14 presents the analogous information for consumer surplus. Taken together, these two graphs tell a good part of the story of what goes on in our data. Consumer surplus' evolution over time is very similar in the different treatments. It is below equilibrium before entry and then moves upward. In all but one treatment, total profits are a little above equilibrium in the incumbency phase. After entry they increase in the two treatments with symmetric firms but decrease and even become negative in the other four treatments.

\subsection{Statistical Analysis}

We first study the overall performance of markets as reflected in consumer surplus and total profit levels and later move to analyzing incumbents' behaviour. ${ }^{11}$ Table 5 presents the results of OLS regressions that study the determinants of consumer surplus. The dependent variables are $\mathrm{Csi}, \mathrm{i}=1,2,3,4$. The label $\mathrm{Cs}$ pertains to the ratio between actual and equilibrium surplus, and the number at the end refers to one of the 10 round blocks, except for the last two treatments where block 1 actually had 20 rounds.

In the first four regressions the exogenous variables are (apart from the constant) dummy variables corresponding to the different (exogenous) treatments. "Short" refers

\footnotetext{
${ }^{11}$ Here and in all subsequent regressions the unit of analysis is the group. The number of observations is 54 and $* * *$ and $* * *$ indicate statistical significance at the $10 \%, 5 \%$ and $1 \%$ levels.
} 
to an initial incumbency phase of ten rounds and "simul" and "seq" have the same meaning as in the treatment labels. The notion here is simply to see by comparison between the four regressions how the exogenous treatments affect behaviour over time. In the last regressions where the endogenous variables are Cs2, Cs3, and Cs4, we include Cs1 as an exogenous variable to check for any level effect of pre-entry behaviour. In these and all our other regressions below, we take each session as a separate data point. In this way our regression analysis is based on statistically independent information.

\begin{tabular}{|c|c|c|c|c|c|c|c|}
\hline \multicolumn{8}{|c|}{ TABLE 5. DETERMINANTS OF CONSUMER SURPLUS } \\
\hline $\begin{array}{c}\text { Dependent } \\
\text { Variable }\end{array}$ & Cs1 & Cs2 & Cs3 & Cs4 & Cs2 & Cs3 & Cs4 \\
\hline Short & $\begin{array}{c}.0543889 \\
(.0806118)\end{array}$ & $\begin{array}{c}-.1506111 \\
(.0623511)^{* *}\end{array}$ & $\begin{array}{c}-.0976667 \\
(.0436902)^{* *}\end{array}$ & $\begin{array}{l}-.0 .333889 \\
(.0550598)\end{array}$ & $\begin{array}{c}-.1638033 \\
(.0600787)^{* * *}\end{array}$ & $\begin{array}{c}-.101013 \\
(.0440476)^{* *}\end{array}$ & $\begin{array}{c}-030654 \\
(.0557198)\end{array}$ \\
\hline Simul & $\begin{array}{c}.0513704 \\
(.0658192)\end{array}$ & $\begin{array}{c}.1057407 \\
(.0509095)^{* *}\end{array}$ & $\begin{array}{c}.0347037 \\
(.0356729)\end{array}$ & $\begin{array}{l}-.0574444 \\
(.0449562)\end{array}$ & $\begin{array}{c}.0932807 \\
(.0491289)^{*}\end{array}$ & $\begin{array}{c}.0315431 \\
(.0360195)\end{array}$ & $\begin{array}{l}-.0548613 \\
(.0455644)\end{array}$ \\
\hline Sym & $\begin{array}{c}.0573889 \\
(.0806118)\end{array}$ & $\begin{array}{l}-.0129444 \\
(.0623511)\end{array}$ & $\begin{array}{c}-.2093889 \\
(.0436902) * * *\end{array}$ & $\begin{array}{c}-.1194444 \\
(.0550598)^{* * *}\end{array}$ & $\begin{array}{l}-.0268643 \\
(.0601095)\end{array}$ & $\begin{array}{c}-.2129198 \\
(.0440701)^{* * *}\end{array}$ & $\begin{array}{c}-.1165587 \\
(.0557483)^{* *}\end{array}$ \\
\hline Cs1 & - & - & & - & $\begin{array}{c}.2425536 \\
(.1049227)^{* *}\end{array}$ & $\begin{array}{c}.0615261 \\
(.0769256)\end{array}$ & $\begin{array}{l}-.0502839 \\
(.0973102)\end{array}$ \\
\hline Constant & $\begin{array}{c}.5533148 \\
(.0658192)^{* * * *}\end{array}$ & $\begin{array}{c}.9653519 \\
(.0509095)^{* * *}\end{array}$ & $\begin{array}{c}1.207648 \\
(.0356729)^{* * *}\end{array}$ & $\begin{array}{c}1.102444 \\
(.0449562)^{* *} \\
*\end{array}$ & $\begin{array}{c}.8311433 \\
(.0758618)^{* * *}\end{array}$ & $\begin{array}{c}1.173605 \\
(.0556192)^{* * *}\end{array}$ & $\begin{array}{c}1.130267 \\
(.0703577)^{* * *}\end{array}$ \\
\hline $\begin{array}{c}\text { Adjusted } \\
\mathrm{R}^{2}\end{array}$ & -.01 & .16 & .48 & .12 & .22 & .48 & .11 \\
\hline
\end{tabular}

The table shows the value of the coefficient and the standard error in parentheses; negative coefficients indicate a worsening of the attained consumer surplus with respect to the equilibrium level. The first regression, with Cs1 as dependent variable, reveals that the collusion that is present in the first ten rounds is, as expected, independent of the treatment varaibles; the strongly significant constant shows that consumer surplus is somewhat above $55 \%$ of its equilibrium.

The next three regressions reflect the impact of the treatment variables over time. The shorter incumbency phase has a significantly negative impact in after-entry 
rounds 11-20 and 21-30, which weakens over time in its magnitude. For after-entry rounds 31-40, the coefficient is no longer significant. Perhaps surprisingly, a shorter incumbency phase leads to higher post-entry tacit collusion.

The simultaneity of entry has a positive impact on the consumer surplus ration in the ten rounds just after the first entry takes place. What seems to matter is the number of firms in the market, which in the first ten after-entry rounds is five under smultaneous entry and only three under sequential entry. Once under sequential entry there are a total of four firms in the market, there is no difference between simultaneity and sequentiality of entry.

Symmetry has a significantly negative effect both in rounds 11-20 and 21-30 after the first entry, but no significant effect before that. This reflects the tendency to some tacit collusion under symmetry, discussed in the previous section. In the last three regressions in Table 5 we control for the consumer surplus ratio in the incumbency phase. As can be seen the presence of Cs1 as control does not affect any of the effect of the treatment variables; however, it does have a significant effect on Cs2, reflecting a carry-over of collusion from the incumbency phase into the first ten after-entry rounds.

\begin{tabular}{|c|c|c|c|c|c|c|c|}
\hline \multicolumn{8}{|c|}{ TABLE 6. DETERMINANTS OF TOTAL PROFITS } \\
\hline $\begin{array}{c}\text { Dependent } \\
\text { Variable }\end{array}$ & Ps1 & Ps2 & Ps3 & Ps4 & Ps2 & Ps3 & Ps4 \\
\hline Short & $\begin{array}{l}.0095 \\
(.0527346)\end{array}$ & $\begin{array}{c}.7348333 \\
(.1635447)^{* * * *}\end{array}$ & $\begin{array}{c}.1731667 \\
(.1971105)\end{array}$ & $\begin{array}{l}.0220778 \\
(.2910852)\end{array}$ & $\begin{array}{c}.7285792 \\
(.1614924)^{* * * *}\end{array}$ & $\begin{array}{l}.1707191 \\
(.1987026)\end{array}$ & $\begin{array}{l}.0089985 \\
(.2848396)\end{array}$ \\
\hline Simu & $\begin{array}{l}-.0044852 \\
(.0430576)\end{array}$ & $\begin{array}{c}-.347963 \\
(.1335337)^{* * *}\end{array}$ & $\begin{array}{l}.1365185 \\
(.1609401)\end{array}$ & $\begin{array}{c}.2856444 \\
(.2376701)\end{array}$ & $\begin{array}{c}.3450102 \\
(.1318295) * *\end{array}$ & $\begin{array}{c}.135363 \\
(.1622049)\end{array}$ & $\begin{array}{c}.2794693 \\
(.2325203)\end{array}$ \\
\hline Sym & $\begin{array}{c}-.12945 \\
(.0527346)^{* *}\end{array}$ & $\begin{array}{c}-.082 \\
(.1635447)\end{array}$ & $\begin{array}{c}.8706667 \\
(.1971105) * * *\end{array}$ & $\begin{array}{c}1.2068 \\
(.2910852)^{* * *}\end{array}$ & $\begin{array}{c}.0032209 \\
(.1708913)\end{array}$ & $\begin{array}{c}.9040175 \\
(.2102672)^{* * * *}\end{array}$ & $\begin{array}{c}1.028577 \\
(.3014174)^{* * * *}\end{array}$ \\
\hline Ps1 & - & - & - & - & $\begin{array}{c}.6583304 \\
(.4329425)\end{array}$ & $\begin{array}{c}.2576349 \\
(.5326988)\end{array}$ & $\begin{array}{c}-1.376772 \\
(.7636222)^{*}\end{array}$ \\
\hline Constant & $\begin{array}{c}1.067298 \\
(.0430576)^{* * *}\end{array}$ & $\begin{array}{c}.4503704 \\
(.1335337)^{* * * *}\end{array}$ & $\begin{array}{c}.1463704 \\
(.1609401)\end{array}$ & $\begin{array}{l}-.0689333 \\
(.2376701)\end{array}$ & $\begin{array}{l}-.2522644 \\
(.4805122)\end{array}$ & $\begin{array}{l}-.1286029 \\
(.5912293)\end{array}$ & $\begin{array}{c}1.400493 \\
(.8475255)\end{array}$ \\
\hline $\begin{array}{c}\text { Adjusted } \\
\mathrm{R}^{2}\end{array}$ & .08 & .35 & .36 & .28 & .36 & .35 & .31 \\
\hline
\end{tabular}


Table 6 shows regression results corresponding to total profits (producer surplus). The variables Psi $\mathrm{i}=12,3,4$ denote producer surplus as a ratio of equilibrium producer surplus for the four ten round blocks after entry. In the first regression, with Ps1 as dependent variable, the simultaneity of entry has a significant effect, for which we have no good explanation. Moving to the next three regressions, one can see that in the first ten after-entry rounds a shorter incumbency phase actually helps to keep profits up, in a way an anti-inertia result, but has no effect in the subsequent twenty rounds. This is consistent with the results for consumer surplus, reported above. The simultaneity dummy has a significantly negative effect for Ps2, but no significant effect on Ps3 and Ps4. It is as if the simultaneous entry had initially a shock-effect, to which firms later learn to adapt.

The symmetry dummy has a significantly positive effect on Ps3 and Ps4. Comparing again figures 1 and 4 on one hand and 2 and 6 on the other hand helps interpret this finding. In the asymmetric cases incumbent firms frequently resist leaving the market, even if this implies negative profits.

The last three regressions in Table 6 reveal that the effects of the treatment variables are essentially not affected by the inclusion of Ps1 as exogenous variable, which does have a positive effect in the first ten rounds after entry.

We now move to studying more formally incumbents' output decisions. In Table 7 we can see the impact of the treatment variables on the variables denoted by Msdi=((incumbents' profits/total profits) - (incumbents' equilibrium profits/total equilibrium profits)), $\mathrm{i}=1,2,3$, where Msd is an acronym for market share difference. The subscript refers here to blocks of rounds after the incumbency phase since during this phase Msd is by definition zero. In equilibrium this variable is always equal to zero; positive values correspond to incumbents being able to hold on to market share after entry. The first three regressions' exogenous variables are again the treatment variables, in the last three regressions we condition on Ps1, a measure of collusion in the incumbency phase.

Here we can see that symmetry has a significantly negative impact on the Msd variable. Consistent with what we have seen above, in the asymmetric treatments the incumbents are able to maintain larger than equilibrium market shares to a statistically significant degree. The length of the incumbency phase also has a statistically significant impact, negative in the first ten post-entry rounds and positive in the second ten post-entry rounds. 


\begin{tabular}{|c|c|c|c|c|c|c|}
\hline \multicolumn{7}{|c|}{$\begin{array}{c}\text { TABLE 7. INCUMBENTS' MARKET SHARE DEVIATIONS FR } \\
\text { EQUILIBRIUM }\end{array}$} \\
\hline $\begin{array}{l}\text { Dependent } \\
\text { Variable }\end{array}$ & Msd1 & Msd2 & $\mathrm{Msd} 3$ & Msd1 & Msd2 & Msd3 \\
\hline Short & $\begin{array}{c}-.6799444 \\
(.2599711)^{* *}\end{array}$ & $\begin{array}{l}-.0643889 \\
(.1095199)\end{array}$ & $\begin{array}{c}-.341 \\
(.2529475)\end{array}$ & $\begin{array}{c}-.6804922 \\
(.2626777)^{* *}\end{array}$ & $\begin{array}{l}.0643049 \\
(.1106667)\end{array}$ & $\begin{array}{l}.3429576 \\
(.2553625)\end{array}$ \\
\hline Simul & $\begin{array}{l}.2 .425185 \\
(.2122655)\end{array}$ & $\begin{array}{c}.0293333 \\
(.0894226)\end{array}$ & $\begin{array}{l}-.1174444 \\
(.2065307)\end{array}$ & $\begin{array}{c}.2422599 \\
(.21444292)\end{array}$ & $\begin{array}{l}-.0292937 \\
(.0903395)\end{array}$ & $\begin{array}{l}-.1165202 \\
(.2084576)\end{array}$ \\
\hline Sym & $\begin{array}{c}.3244444 \\
(.2599711)\end{array}$ & $\begin{array}{c}-.4128333 \\
(.1095199)^{* * *}\end{array}$ & $\begin{array}{c}.0391667 \\
(.2529475)\end{array}$ & $\begin{array}{c}.3319078 \\
(.2779657)\end{array}$ & $\begin{array}{c}-.4139782 \\
(.1171076)^{* * *}\end{array}$ & $\begin{array}{c}.0658412 \\
(.2702247)\end{array}$ \\
\hline Ps1 & - & - & - & $\begin{array}{c}.0576542 \\
(.7042088)\end{array}$ & $\begin{array}{l}-.0088444 \\
(.2966847)\end{array}$ & $\begin{array}{r}.2060606 \\
(.6845974)\end{array}$ \\
\hline Constant & $\begin{array}{c}.4848148 \\
(.2122655)^{* *}\end{array}$ & $\begin{array}{c}.4242778 \\
(.0894226)^{* * * *}\end{array}$ & $\begin{array}{c}.3557222 \\
(.2065307)^{*}\end{array}$ & $\begin{array}{l}.4232806 \\
(.781584)\end{array}$ & $\begin{array}{c}.4337174 \\
(.3292831)\end{array}$ & $\begin{array}{c}.1357941 \\
(.7598179)\end{array}$ \\
\hline $\begin{array}{c}\text { Adjusted } \\
\mathrm{R}^{2}\end{array}$ & .09 & .27 & .01 & .07 & .25 & -.02 \\
\hline
\end{tabular}

We can now formulate four regularities that answer the four research questions that we posed in section 2.1. In the concluding section we discuss their implications.

Regularity 1: When firms are identical, consumer and total surplus reach equilibrium levels after enough entry. When incumbents are less efficient than entrants consumer surplus tends to equilibrium but total surplus remains considerably below equilibrium. These results are independent of whether entry is sequential or simultaneous and of the length of the incumbency phase.

Regularity 2: When firms are identical, incumbents are not able to hold on to a larger than equilibrium market share. When incumbents are less efficient than entrants, incumbents' post-entry actual market shares are significantly larger than in equilibrium.

Regularity 3: Whether entry is simultaneous or sequential has no effect on consumer surplus, total surplus, and incumbent market shares.

Regularity 4: A shorter incumbency phase leads to lower consumer surplus and higher profits in rounds 21-30 after first entry. It has a significantly negative impact on incumbents' market in rounds 11-20 and to a significantly positive impact in rounds 2130 . 


\section{Concluding remarks}

We can now get back to the major themes that we presented in the introduction to the paper. The experiments we present in this paper are meant to be a contribution to the understanding of the market selection process. We find that in the different treatments with asymmetric firms, incumbents produce significantly more and entrants significantly less of what the relevant equilibrium prescribes. Consistent with this, profit levels in these markets are substantially below equilibrium.

The replacement of inefficient firms by more efficient ones is, in our environment, not a clean process; it takes place with some turbulence. This is perhaps the main idea to take away from our work: market selection of more efficient firms works eventually, but during a certain transition phase some of the agents in the market will oppose market forces and, by doing so, distort market signals. This occurs in an environment in which incumbents do not have any strategic advantage in terms of an entry cost or any other factor.

It is interesting that in the symmetric markets of our treatments with symmetric firms, we do not observe significant incumbency advantages. This suggests that observed behavior in the asymmetric markets is not just the result of incumbents having "deep pockets" due to the accumulated earnings from the duopoly phase. There is something in the characteristics of the asymmetric equilibrium that is difficult for participants to gauge or accept. One possibility is that in the experiment incumbents resisted obtaining lower payments in the experimental currency. However, we used different conversion rates for participants with different entry points. Also, when entry occurs incumbents have had an incumbency phase behind them in which they have been able to accumulate earnings, so that from the point of view of relative payoffs incumbents should not necessarily feel they are behind.

Perhaps incumbents' behavior is driven by some sense of entitlement. Simon $(1955,1959)$ introduced the idea that decision makers satisfice (instead of optimizing) and that what they find satisfactory is a function of, among other things, past experience. From here the notion of aspiration levels emerged. In their study of the merger paradox Huck et al. (2007) study mergers and entry under quantity competition with firms with identical cost functions. They find that merged firms retain, after the merger, larger than equilibrium market shares. In their entry treatment one firm is added to a market with 3 incumbents who had interacted over 25 rounds. The result is that the 
three entrants retain, after entry, larger market shares than the identical entrant. They show that their set of treatments is consistent with the notion of aspiration levels.

Our results for the asymmetric treatments (incumbents' resistance to entrants) are consistent with those of Huck et al. (2007), but our results in the symmetric treatments are not. The environment we study differs in several respects from theirs, so it is not easy to attribute the difference to one particular feature. One important difference pertains to the numbers of incumbents and entrants. In the entry treatment of Huck et al. (2007), one additional firm enters a market of three incumbent firms, whereas in our case there are two incumbents and three entrants. One possible explanation of the discrepancy of results is that behavior is influenced by the perception that the relative strength of incumbents and entrants depends on how many firms are in the two groups. In addition, in Huck et al. (2007) the incumbency phase lasted for 25 rounds, and this can have solidified incumbents' aspiration levels and their perception by entrants. A third important difference between the two designs is that, in our case, incumbents and entrants knew beforehand at what point in time each of the entrants would be given access to the market. In addition, entrants who had not yet been given access to the market received information about the total output produced. In our design the market is more transparent. In the symmetric treatments this may induce the entrants to be less cautious, and, anticipating this, the incumbents to adjust accordingly.

Another explanation of the difference in results is that the fact of having been in the market first gives incumbents some sense of superiority vis-à-vis the entrants. Camerer and Lovallo (1999) use experiments to study excess entry into markets and attribute it to overconfidence. In another experimental study Grieco et al. (200t) explain excess entry in terms of people seeking ambiguity when the source of uncertainty is related to their self-assessed competence, in the spirit of Heath and Tversky (1991). The question arises whether issues of overconfidence and self-assessed competence also play a role in our context. Perhaps symmetric entrants feel somehow more competent about making choices than asymmetric entrants. This could allow incumbents to hold on to a part of the market for a while, leading to the noisy adjustment process that we observe in some of our treatments.

It is worth reiterating here that the incumbency advantage that we observe does not hurt consumers. The fights for the market between incumbents and entrants lead to large output levels and low prices. However, production inefficiencies are considerable and lead to total surplus levels of about $80 \%$ of the equilibrium levels. 
The fact that incumbents often earn negative profits when they behave in such a way indicates that it will not be sustainable in the long-run. We conjecture that after enough time behavior will resemble rather closely the one corresponding to the Cournot equilibrium. Nevertheless, the behavior we observe does not appear to be a feature of only the very short run.

\section{REFERENCES}

Abbink, K., Brandts, J., McDaniel, T.M., 2003. Asymmetric demand information in uniform and discriminatory call auctions: an experimental analysis motivated by electricity markets. Journal of Regulatory Economics 23, 125-144.

Bain, J., 1956. Barriers to new competition. Cambridge: Harvard University Press.

Basu, K., 1993. Lectures in industrial organization theory. Oxford: Blackwell Publishers.

Borenstein, S., Bushnell, J., 1999. An empirical analysis of the potential for market power in California's electricity industry. Journal of Industrial Economics 47, 285-323.

Brandts, J., Cabrales, A., Charness, G., 2007. Forward induction and entry deterrence: an experiment. Economic Theory 33, 183-209.

Brandts, J., Cooper, D., 2006. A change would do you good: an experimental study of how to overcome coordination failure in organizations. American Economic Review 96, 669-693.

Brandts, J., Pezanis-Christou, P., Schram, A., 2008. Competition with forward contracts: a laboratory analysis motivated by electricity market design. The Economic Journal 118, 192-214.

Bresnahan, T., Reiss, P., 1991. Entry and competition in concentrated markets. Journal of Political Economy 99, 977-1009.

Camerer, C., Lovallo, D., 1999. Overconfidence and excess entry: an experimental approach. American Economic Review 89, 306-318.

Caves, R., 1998. Industrial organization and new findings on the turnover and mobility of firms. Journal of Economic Literature 36, 1947-1982.

Ericson, R., Pakes, A., 1995. Markov-perfect industry dynamics: a framework for empirical work. Review of Economic Studies 62, 53-82.

Fischbacher, U., 2007. z-tree: Zurich toolbox for ready-made economics experiments. Experimental Economics 10, 171-178.

Grieco, D., Hogarth, R., Karelaia, N., 2007. Risk-taking and excess entry: the roles of confidence and fallible judgement. http://www.gate.cnrs.fr/ewebe2/papiers/hogarth.pdf.

Heath, C., Tversky, A., 1991. Preference and belief: ambiguity and competence in choice under uncertainty. Journal of Risk and Uncertainty 4, 5-28. 
Holt, C., 1995. Industrial organization: a survey of laboratory research. In: Kagel, J., Roth, A. (Eds.). The Handbook of Experimental Economics. Princeton: Princeton University Press, 349443.

Hopenhayn, H., 1992. Entry, exit and firm dynamics in long run equilibrium. Econometrica 60, 1127-1150.

Huck, S., Konrad, K. A., Müller, W., Normann, H.-T., 2007. The merger paradox and why aspiration levels let it fail in the laboratory. The Economic Journal 117, 1073-1095.

Huck, S., Normann, H-T., Oechssler, J., 2000. Does information about competitors' actions increase or decrease competition in experimental oligopoly markets. International Journal of Industrial Organization 18, 39-58.

Huck, S., Normann, H-T., Oechssler, J., 2004. Two are few and four are many: number effects in experimental oligopoly. Journal of Economic Behavior and Organization 53, 435-446.

Isaac. R., Smith, V., 1985. In search of predatory pricing. Journal of Political Economy 93, 320345.

Jovanovic, B., 1982. Selection and the evolution of industry. Econometrica 50, 649-670.

Jung, Y., Kagel, J., Levin, D., 1994. On the existence of predatory pricing. An experimental study of reputation effects in a chain store game. RAND Journal of Economics 25, 72-93.

Kerin, R., Varadarajan, R., Peterson, R., 1992. First-mover advantage: a synthesis, conceptual framework, and research propositions. Journal of Marketing 56, 33-52.

Lieberman, M., Montgomery, D., 1988. First-mover advantages. Strategic Management Journal 9, 41-58.

Lieberman, M., Montgomery, D., 1998. First-mover (dis)advantages: retrospective and link with the resource-based view. Strategic Management Journal 19, 1111-1125.

Martin, S., 1993. Advanced industrial economics. Oxford: Basil Blackwell.

Mueller, D., 1997. First-mover advantage and path dependence. International Journal of Industrial Organization 15, 827-850.

Muller, R., Sadanand, A., 2003. Order of play, forward induction, and presentation effects in two-person games. Experimental Economics 6, 5-25.

Normann, H.-T., 2006. Experimental economics for antitrust law and policy. http://search.ssrn.com/sol3/papers.cfm?abstract_id=950206.

Plott, C., 1997. Laboratory experimental testbed. Application to the PCS auction. Journal of Economics and Management Strategy 6, 605-638.

Plott, C., Salmon, T., 2004. The simultaneous, ascending auction: dynamics of price adjustment in experiments and in the U.K. 3G spectrum auction. Journal of Economic Behavior and Organization 53, 353-383.

Rapoport, A., 1997. Order of play in strategically-equivalent games in extensive form. International Journal of Game Theory 26, 113-136. 
Rapoport, A., Budescu, D., Suleiman, R., 1993. Sequential requests from randomly-distributed shared resources. Journal of Mathematical Psychology 37, 241-265.

Rapoport, A., Weg, E., Felsenthal, D., 1990. Effects of fixed costs in two-person sequential bargaining. Theory and Decision 28, 47-71.

Rassenti, S., Smith, V., Wilson, B., 2003. Controlling market power and price spikes in electricity networks: demand-side bidding. Proceedings of the National Academy of Science 100, 2998-3003.

Rassenti, S., Smith, V., Wilson, B., 2003. Discriminatory price auctions in electricity markets: low volatility at the expense of high price levels. Journal of Regulatory Economics 23, 109-123.

Rassenti, S., Smith, V., Wilson, B., 2002. Using experiments to inform the privatization/deregulation movement in electricity. The Cato Journal 21, 515-544.

Roberts, M., Tybout, J., 1997. Producer turnover and productivity growth in developing countries. World Bank Research Observer 12, 1-18.

Robinson, W., Kalyanaram, G., Urban, G., 1994. First-mover advantages from pioneering new markets: a survey of empirical evidence. Review of Industrial Organization 9, 1-23.

Simon, H. A., 1955. A behavioral model of rational choice. Quarterly Journal of Economics 69, 99-118.

Simon, H. A., 1959. Theories of decision making in economics and behavioral science. American Economic Review 49, 253-283.

Sylos-Labini, P., 1962. Oligopoly and technical progress. Cambridge: Harvard University Press.

Tirole, J., 1989. The theory of industrial organization. Cambridge: MIT Press.

Vives, X., 1999. Oligopoly pricing: old ideas and new tools. Cambridge: MIT Press.

Weber, R., Camerer, C., Knez, M., 2004. Timing and virtual observability in ultimatum games and 'weak link' coordination games. Experimental Economics 7, 25-48.

Zahra, S., Nash, S., Bickford, D., 1995. Transforming technological pioneering into competitive advantage. Academy of Management Executive 9, 17-31. 
Table 3. Total Quantity (actual vs. equilibrium)

\begin{tabular}{|c|c|c|c|c|c|c|c|c|c|c|c|c|}
\hline \multirow[b]{2}{*}{ Period } & \multicolumn{2}{|c|}{$\begin{array}{c}\text { TREATMENT } \\
\text { Seq-Sym10 }\end{array}$} & \multicolumn{2}{|c|}{$\begin{array}{l}\text { TREATMENT } \\
\text { Simul-Sym10 }\end{array}$} & \multicolumn{2}{|c|}{$\begin{array}{l}\text { TREATMENT } \\
\text { Seq-Asym10 }\end{array}$} & \multicolumn{2}{|c|}{$\begin{array}{l}\text { TREATMENT } \\
\text { Simul-Asym10 }\end{array}$} & \multicolumn{2}{|c|}{$\begin{array}{l}\text { TREATMENT } \\
\text { Seq-Asym20 }\end{array}$} & \multicolumn{2}{|c|}{$\begin{array}{l}\text { TREATMENT } \\
\text { Simul-Asym20 }\end{array}$} \\
\hline & Q(equ.) & $\begin{array}{c}\text { Q(actual } \\
\text { ) }\end{array}$ & $\mathbf{Q}$ (equ.) & $\begin{array}{c}\mathbf{Q} \\
\text { (actual) }\end{array}$ & $\mathbf{Q}$ (Equ.) & $\begin{array}{c}\mathbf{Q} \\
\text { (Actual) }\end{array}$ & $\mathbf{Q}$ (equ.) & $\begin{array}{c}\mathbf{Q} \\
\text { (actual) }\end{array}$ & $\mathbf{Q}$ (equ.) & $\begin{array}{c}\mathbf{Q} \\
\text { (actual) }\end{array}$ & $\mathbf{Q}$ (equ.) & $\begin{array}{c}\mathbf{Q} \\
\text { (actual) }\end{array}$ \\
\hline 1 & 40 & 28.11 & 40 & 22,79 & 60 & 39.67 & 60 & 30.44 & 60 & 36.33 & 60 & 32.89 \\
\hline 2 & 40 & 30.78 & 40 & 24,55 & 60 & 45 & 60 & 31.33 & 60 & 36.56 & 60 & 34.44 \\
\hline 3 & 40 & 28.89 & 40 & 26,55 & 60 & 44.11 & 60 & 41.11 & 60 & 45.78 & 60 & 38.56 \\
\hline 4 & 40 & 28.78 & 40 & 29,33 & 60 & 43.78 & 60 & 45.11 & 60 & 45.67 & 60 & 44.44 \\
\hline 5 & 40 & 28.22 & 40 & 33 & 60 & 47.67 & 60 & 42.89 & 60 & 46.78 & 60 & 37.78 \\
\hline 6 & 40 & 29.44 & 40 & 35,33 & 60 & 44.56 & 60 & 46 & 60 & 47.11 & 60 & 40 \\
\hline 7 & 40 & 30.22 & 40 & 35,44 & 60 & 44.56 & 60 & 48.67 & 60 & 49.11 & 60 & 43.78 \\
\hline 8 & 40 & 30.78 & 40 & 38,22 & 60 & 45.56 & 60 & 51.89 & 60 & 48.11 & 60 & 45.33 \\
\hline 9 & 40 & 33.11 & 40 & 37,67 & 60 & 48.78 & 60 & 49.67 & 60 & 48.11 & 60 & 38 \\
\hline 10 & 40 & 34.22 & 40 & 36,33 & 60 & 46.11 & 60 & 47.78 & 60 & 46.89 & 60 & 42.44 \\
\hline 11 & 45 & 46.11 & 50 & 59,99 & 70 & 59.44 & 75 & 80.89 & 60 & 49.56 & 60 & 45 \\
\hline 12 & 45 & 35 & 50 & 44,77 & 70 & 56.67 & 75 & 77.56 & 60 & 51.11 & 60 & 49.78 \\
\hline 13 & 45 & 34 & 50 & 40,65 & 70 & 62.44 & 75 & 70.33 & 60 & 50.22 & 60 & 49.56 \\
\hline 14 & 45 & 37.67 & 50 & 43,45 & 70 & 65.56 & 75 & 72.11 & 60 & 50.56 & 60 & 50.44 \\
\hline 15 & 45 & 39.78 & 50 & 48,88 & 70 & 56 & 75 & 65.22 & 60 & 52.22 & 60 & 51.56 \\
\hline 16 & 45 & 36.11 & 50 & 43,45 & 70 & 63.44 & 75 & 73.67 & 60 & 49.67 & 60 & 48.44 \\
\hline 17 & 45 & 37.56 & 50 & 47,99 & 70 & 65.89 & 75 & 76.11 & 60 & 51.33 & 60 & 50.89 \\
\hline 18 & 45 & 38.67 & 50 & 44,33 & 70 & 61.22 & 75 & 73.67 & 60 & 51.11 & 60 & 52.67 \\
\hline 19 & 45 & 36.89 & 50 & 45,78 & 70 & 62.89 & 75 & 67.67 & 60 & 51.67 & 60 & 53.22 \\
\hline 20 & 45 & 38.67 & 50 & 50,78 & 70 & 64.11 & 75 & 68.56 & 60 & 52.67 & 60 & 49.11 \\
\hline 21 & 48 & 45.78 & 50 & 49,23 & 66 & 67.56 & 75 & 76.44 & 70 & 59.44 & 75 & 82 \\
\hline 22 & 48 & 40.22 & 50 & 47 & 66 & 61.78 & 75 & 72.89 & 70 & 57.22 & 75 & 54.67 \\
\hline 23 & 48 & 43.78 & 50 & 46,55 & 66 & 70.33 & 75 & 73.22 & 70 & 59.89 & 75 & 60.89 \\
\hline 24 & 48 & 43.33 & 50 & 48,21 & 66 & 78.11 & 75 & 73.44 & 70 & 64.22 & 75 & 73 \\
\hline 25 & 48 & 41.67 & 50 & 50,22 & 66 & 77.56 & 75 & 75.89 & 70 & 61.22 & 75 & 73.56 \\
\hline 26 & 48 & 46.44 & 50 & 51 & 66 & 63.56 & 75 & 76.22 & 70 & 64.78 & 75 & 73.22 \\
\hline 27 & 48 & 42.22 & 50 & 50,89 & 66 & 62 & 75 & 78.11 & 70 & 61.89 & 75 & 78.22 \\
\hline 28 & 48 & 47.78 & 50 & 44,43 & 66 & 68.11 & 75 & 73.78 & 70 & 62.22 & 75 & 74.44 \\
\hline 29 & 48 & 47.56 & 50 & 47,23 & 66 & 70 & 75 & 77 & 70 & 62.78 & 75 & 83.22 \\
\hline 30 & 48 & 44.22 & 50 & 47,21 & 66 & 73.78 & 75 & 77.89 & 70 & 66.67 & 75 & 71.89 \\
\hline 31 & 50 & 48.89 & 50 & 47,54 & 75 & 79.89 & 75 & 80.11 & 66 & 79.89 & 75 & 71.89 \\
\hline 32 & 50 & 48.78 & 50 & 47,21 & 75 & 70.11 & 75 & 77.11 & 66 & 67 & 75 & 74.67 \\
\hline 33 & 50 & 43.89 & 50 & 50,65 & 75 & 77.67 & 75 & 77 & 66 & 68.22 & 75 & 77.78 \\
\hline 34 & 50 & 44.78 & 50 & 47,45 & 75 & 75.22 & 75 & 73.11 & 66 & 71.11 & 75 & 76.89 \\
\hline 35 & 50 & 48.78 & 50 & 49,98 & 75 & 74.89 & 75 & 77.44 & 66 & 71.56 & 75 & 82.22 \\
\hline 36 & 50 & 51.67 & 50 & 43,9 & 75 & 83.89 & 75 & 81.78 & 66 & 71.89 & 75 & 73.78 \\
\hline 37 & 50 & 50.89 & 50 & 44,32 & 75 & 76.78 & 75 & 80 & 66 & 75.22 & 75 & 78.33 \\
\hline 38 & 50 & 44.67 & 50 & 44,95 & 75 & 77.11 & 75 & 79 & 66 & 67.67 & 75 & 78.89 \\
\hline 39 & 50 & 48.89 & 50 & 44,21 & 75 & 89.22 & 75 & 76.78 & 66 & 68.11 & 75 & 78.56 \\
\hline 40 & 50 & 45.78 & 50 & 45,74 & 75 & 87.67 & 75 & 74.78 & 66 & 70.11 & 75 & 78.78 \\
\hline 41 & & & & & & & & & 75 & 75.67 & 75 & 73.44 \\
\hline 42 & & & & & & & & & 75 & 66.33 & 75 & 79.67 \\
\hline 43 & & & & & & & & & 75 & 71.11 & 75 & 78 \\
\hline 44 & & & & & & & & & 75 & 69.56 & 75 & 79.22 \\
\hline 45 & & & & & & & & & 75 & 75.33 & 75 & 78.33 \\
\hline 46 & & & & & & & & & 75 & 69.78 & 75 & 84.22 \\
\hline 47 & & & & & & & & & 75 & 72.33 & 75 & 74.56 \\
\hline 48 & & & & & & & & & 75 & 70.56 & 75 & 74.56 \\
\hline 49 & & & & & & & & & 75 & 68.44 & 75 & 82 \\
\hline 50 & & & & & & & & & 75 & 73.56 & 75 & 76.89 \\
\hline
\end{tabular}


Table 4. Total Surplus (actual vs. equilibrium)

\begin{tabular}{|c|c|c|c|c|c|c|c|c|c|c|c|c|}
\hline \multirow[b]{2}{*}{ Period } & \multicolumn{2}{|c|}{$\begin{array}{l}\text { TREATMENT } \\
\text { Seq-Sym } 10\end{array}$} & \multicolumn{2}{|c|}{$\begin{array}{l}\text { TREATMENT } \\
\text { Simul-Sym } 10\end{array}$} & \multicolumn{2}{|c|}{$\begin{array}{l}\text { TREATMENT } \\
\text { Seq-Asym } 10\end{array}$} & \multicolumn{2}{|c|}{$\begin{array}{l}\text { TREATMENT } \\
\text { Simul-Asym10 }\end{array}$} & \multicolumn{2}{|c|}{$\begin{array}{l}\text { TREATMENT } \\
\text { Seq-Asym20 }\end{array}$} & \multicolumn{2}{|c|}{$\begin{array}{l}\text { TREATMENT } \\
\text { Simul-Asym20 }\end{array}$} \\
\hline & $\begin{array}{c}\text { TS } \\
\text { (equ.) }\end{array}$ & $\begin{array}{c}\text { TS } \\
\text { (actual) }\end{array}$ & $\begin{array}{c}\text { TS } \\
\text { (equ.) }\end{array}$ & $\begin{array}{c}\text { TS } \\
\text { (actual) }\end{array}$ & $\begin{array}{c}\text { TS } \\
\text { (equ.) }\end{array}$ & $\begin{array}{c}\text { TS } \\
\text { (actual) }\end{array}$ & $\begin{array}{c}\text { TS } \\
\text { (equ.) }\end{array}$ & $\begin{array}{c}\text { TS } \\
\text { (actual) }\end{array}$ & $\begin{array}{c}\text { TS } \\
\text { (equ.) }\end{array}$ & $\begin{array}{c}\text { TS } \\
\text { (actual) }\end{array}$ & $\begin{array}{c}\text { TS } \\
\text { (equ.) }\end{array}$ & $\begin{array}{c}\text { TS } \\
\text { (actual) }\end{array}$ \\
\hline 1 & 290 & 213.01 & 290 & 191,54 & 300 & 211.24 & 300 & 202.07 & 300 & 186.05 & 300 & 170.97 \\
\hline 2 & 290 & 221.19 & 290 & 204,37 & 300 & 237.88 & 300 & 185.3 & 300 & 189.77 & 300 & 176.7 \\
\hline 3 & 290 & 212.47 & 290 & 218,15 & 300 & 237.74 & 300 & 230.76 & 300 & 233.28 & 300 & 202.49 \\
\hline 4 & 290 & 218.57 & 290 & 235,96 & 300 & 235.12 & 300 & 226.74 & 300 & 233.76 & 300 & 228.18 \\
\hline 5 & 290 & 218.44 & 290 & 257,1 & 300 & 250.99 & 300 & 216.73 & 300 & 243.83 & 300 & 201.89 \\
\hline 6 & 290 & 225.68 & 290 & 269,16 & 300 & 238.38 & 300 & 231.61 & 300 & 244.07 & 300 & 215.04 \\
\hline 7 & 290 & 226.44 & 290 & 269,70 & 300 & 237.56 & 300 & 243.57 & 300 & 252.61 & 300 & 231.24 \\
\hline 8 & 290 & 231.61 & 290 & 282,57 & 300 & 243.39 & 300 & 257.42 & 300 & 248.79 & 300 & 236.59 \\
\hline 9 & 290 & 243.67 & 290 & 280,12 & 300 & 257.57 & 300 & 251.35 & 300 & 247.67 & 300 & 199.82 \\
\hline 10 & 290 & 249.44 & 290 & 273,99 & 300 & 245.27 & 300 & 240.37 & 300 & 241.6 & 300 & 226.78 \\
\hline 11 & 292,5 & 265.72 & 275 & 285 & 325 & 280.75 & 378,75 & 396.23 & 300 & 252.94 & 300 & 238.49 \\
\hline 12 & 292,5 & 224.79 & 275 & 261,81 & 325 & 280.4 & 378,75 & 82.07 & 300 & 261.64 & 300 & 259.63 \\
\hline 13 & 292,5 & 242.44 & 275 & 247,57 & 325 & 295.85 & 378,75 & 281.51 & 300 & 257.81 & 300 & 259.71 \\
\hline 14 & 292,5 & 257.26 & 275 & 257,61 & 325 & 304.86 & 378,75 & 359.78 & 300 & 259.32 & 300 & 264.1 \\
\hline 15 & 292,5 & 262.36 & 275 & 272,62 & 325 & 278.14 & 378,75 & 269.58 & 300 & 266.23 & 300 & 268.13 \\
\hline 16 & 292,5 & 256.86 & 275 & 257,6 & 325 & 300.21 & 378,75 & 361.81 & 300 & 258.45 & 300 & 255.23 \\
\hline 17 & 292,5 & 259.67 & 275 & 270,57 & 325 & 301.18 & 378,75 & 324.16 & 300 & 265.59 & 300 & 267.04 \\
\hline 18 & 292,5 & 264.67 & 275 & 260,45 & 325 & 294.17 & 378,75 & 286.89 & 300 & 266.69 & 300 & 271.61 \\
\hline 19 & 292,5 & 259.53 & 275 & 264,78 & 325 & 296.51 & 378,75 & 328.47 & 300 & 269.43 & 300 & 274.21 \\
\hline 20 & 292,5 & 264.69 & 275 & 276,5 & 325 & 298.32 & 378,75 & 304.68 & 300 & 272.3 & 300 & 258.24 \\
\hline 21 & 285,6 & 264.51 & 275 & 273,39 & 383,1 & 291.09 & 378,75 & 262.8 & 325 & 273.78 & 378,75 & 287.91 \\
\hline 22 & 285,6 & 252.93 & 275 & 268,1 & 383,1 & 269.2 & 378,75 & 275.38 & 325 & 269.81 & 378,75 & 213.79 \\
\hline 23 & 285,6 & 270.64 & 275 & 266,91 & 383,1 & 303.73 & 378,75 & 339.86 & 325 & 276.95 & 378,75 & 251.16 \\
\hline 24 & 285,6 & 269.22 & 275 & 271,10 & 383,1 & 319.37 & 378,75 & 320.68 & 325 & 295.72 & 378,75 & 286.11 \\
\hline 25 & 285,6 & 262.57 & 275 & 275,44 & 383,1 & 316.11 & 378,75 & 272.77 & 325 & 288.18 & 378,75 & 285.37 \\
\hline 26 & 285,6 & 274.62 & 275 & 276,90 & 383,1 & 282.88 & 378,75 & 318.78 & 325 & 298.38 & 378,75 & 287.72 \\
\hline 27 & 285,6 & 266.58 & 275 & 276,69 & 383,1 & 277.89 & 378,75 & 360.87 & 325 & 293.28 & 378,75 & 289.72 \\
\hline 28 & 285,6 & 274.36 & 275 & 260,76 & 383,1 & 291.48 & 378,75 & 242.58 & 325 & 291.06 & 378,75 & 280.83 \\
\hline 29 & 285,6 & 279.69 & 275 & 268,70 & 383,1 & 299.12 & 378,75 & 269.69 & 325 & 295.87 & 378,75 & 285.09 \\
\hline 30 & 285,6 & 270.27 & 275 & 268,65 & 383,1 & 313.89 & 378,75 & 381.15 & 325 & 302.64 & 378,75 & 277.24 \\
\hline 31 & 275 & 272.29 & 275 & 269,48 & 378,75 & 293.25 & 378,75 & 430.63 & 383,1 & 304.61 & 378,75 & 291.12 \\
\hline 32 & 275 & 254.79 & 275 & 268,64 & 378,75 & 276.01 & 378,75 & 331.3 & 383,1 & 283.21 & 378,75 & 295.22 \\
\hline 33 & 275 & 261.54 & 275 & 276,27 & 378,75 & 277.73 & 378,75 & 294.56 & 383,1 & 287.79 & 378,75 & 305.58 \\
\hline 34 & 275 & 259.66 & 275 & 269,24 & 378,75 & 287.08 & 378,75 & 296.62 & 383,1 & 296.66 & 378,75 & 296.36 \\
\hline 35 & 275 & 269.83 & 275 & 274,96 & 378,75 & 288.91 & 378,75 & 304.23 & 383,1 & 302.16 & 378,75 & 299.43 \\
\hline 36 & 275 & 275.54 & 275 & 259,09 & 378,75 & 307.33 & 378,75 & 272.56 & 383,1 & 302.04 & 378,75 & 274.56 \\
\hline 37 & 275 & 269.09 & 275 & 260,41 & 378,75 & 286.15 & 378,75 & 315.47 & 383,1 & 300.27 & 378,75 & 286.01 \\
\hline 38 & 275 & 253.13 & 275 & 262,36 & 378,75 & 299.01 & 378,75 & 180.33 & 383,1 & 290.62 & 378,75 & 299.47 \\
\hline 39 & 275 & 265.67 & 275 & 260,07 & 378,75 & 315.03 & 378,75 & 330.19 & 383,1 & 292.78 & 378,75 & 305.26 \\
\hline 40 & 275 & 255 & 275 & 264,65 & 378,75 & 301.68 & 378,75 & 342.76 & 383,1 & 302.35 & 378,75 & 302.28 \\
\hline 41 & & & & & & & & & 378,75 & 280.78 & 378,75 & 293.92 \\
\hline 42 & & & & & & & & & 378,75 & 265.75 & 378,75 & 304.82 \\
\hline 43 & & & & & & & & & 378,75 & 268.09 & 378,75 & 305.21 \\
\hline 44 & & & & & & & & & 378,75 & 276.04 & 378,75 & 312.56 \\
\hline 45 & & & & & & & & & 378,75 & 291.9 & 378,75 & 308.35 \\
\hline 46 & & & & & & & & & 378,75 & 270.54 & 378,75 & 312.96 \\
\hline 47 & & & & & & & & & 378,75 & 281.56 & 378,75 & 298.40 \\
\hline 48 & & & & & & & & & 378,75 & 278.44 & 378,75 & 304.81 \\
\hline 49 & & & & & & & & & 378,75 & 266.84 & 378,75 & 307.28 \\
\hline 50 & & & & & & & & & 378,75 & 288.38 & 378,75 & 294.2 \\
\hline
\end{tabular}


Figure 1: Average q across firm types for Treatment Seq-Sym10

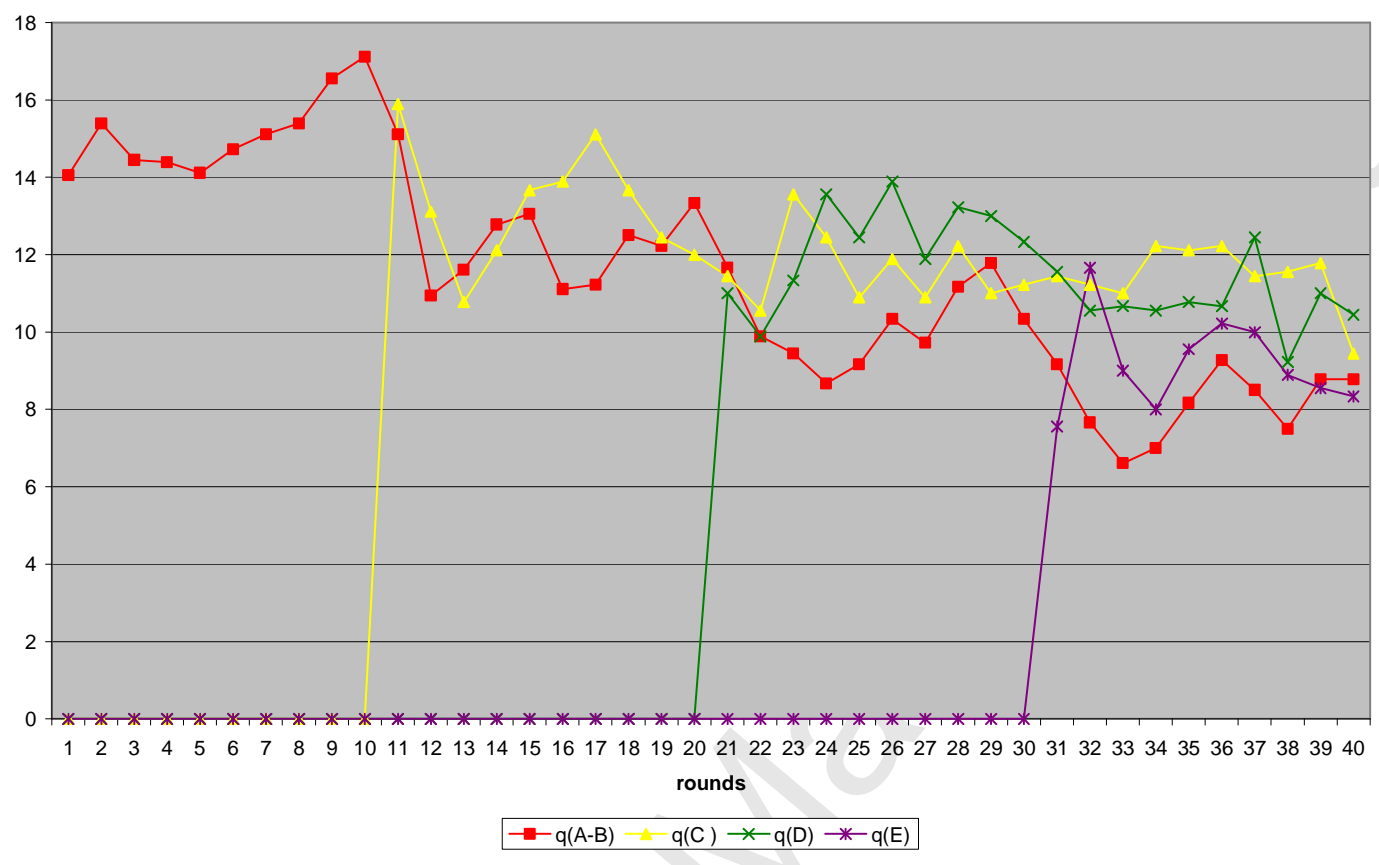

Figure 2: Average q (incumbents vs. entrants) for Treatment Simul-Sym10

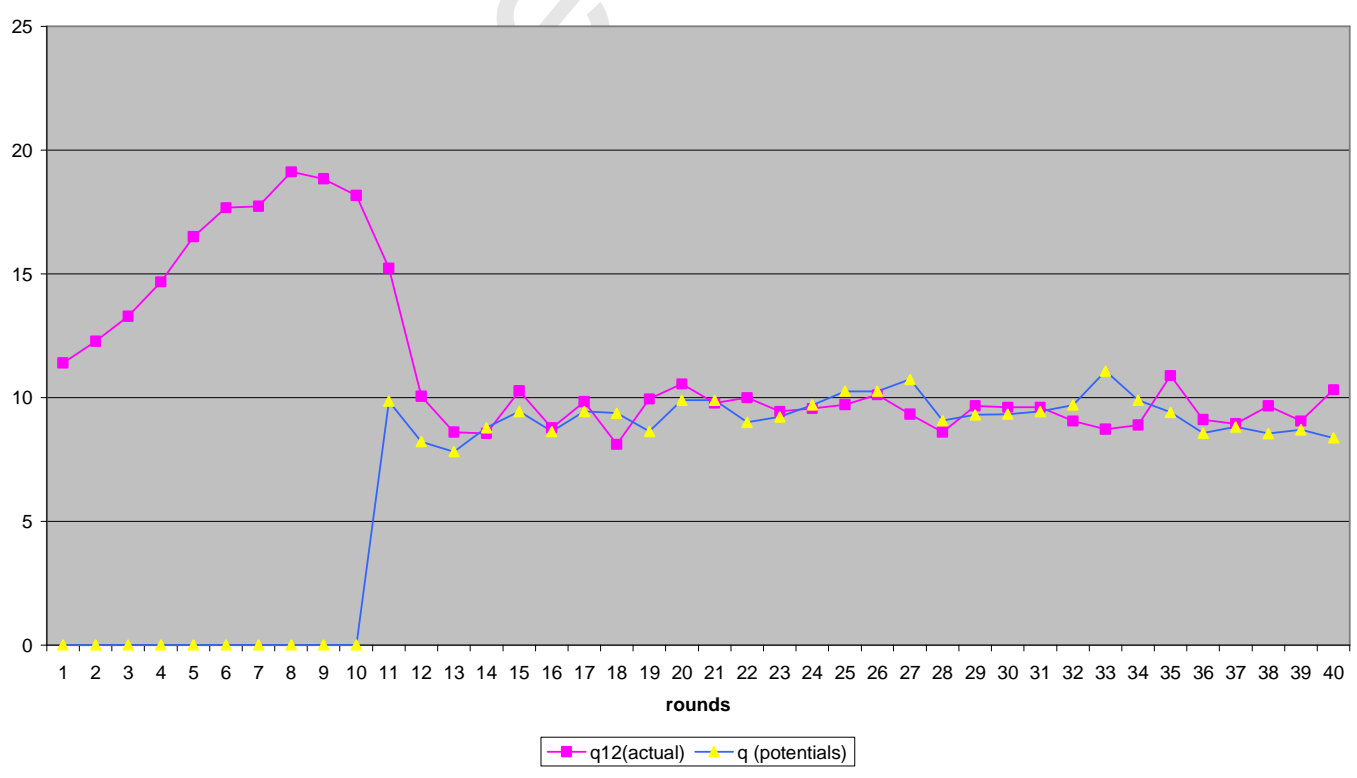


Figure 3: Average q across firm groups for Treatment Seq-Asym10

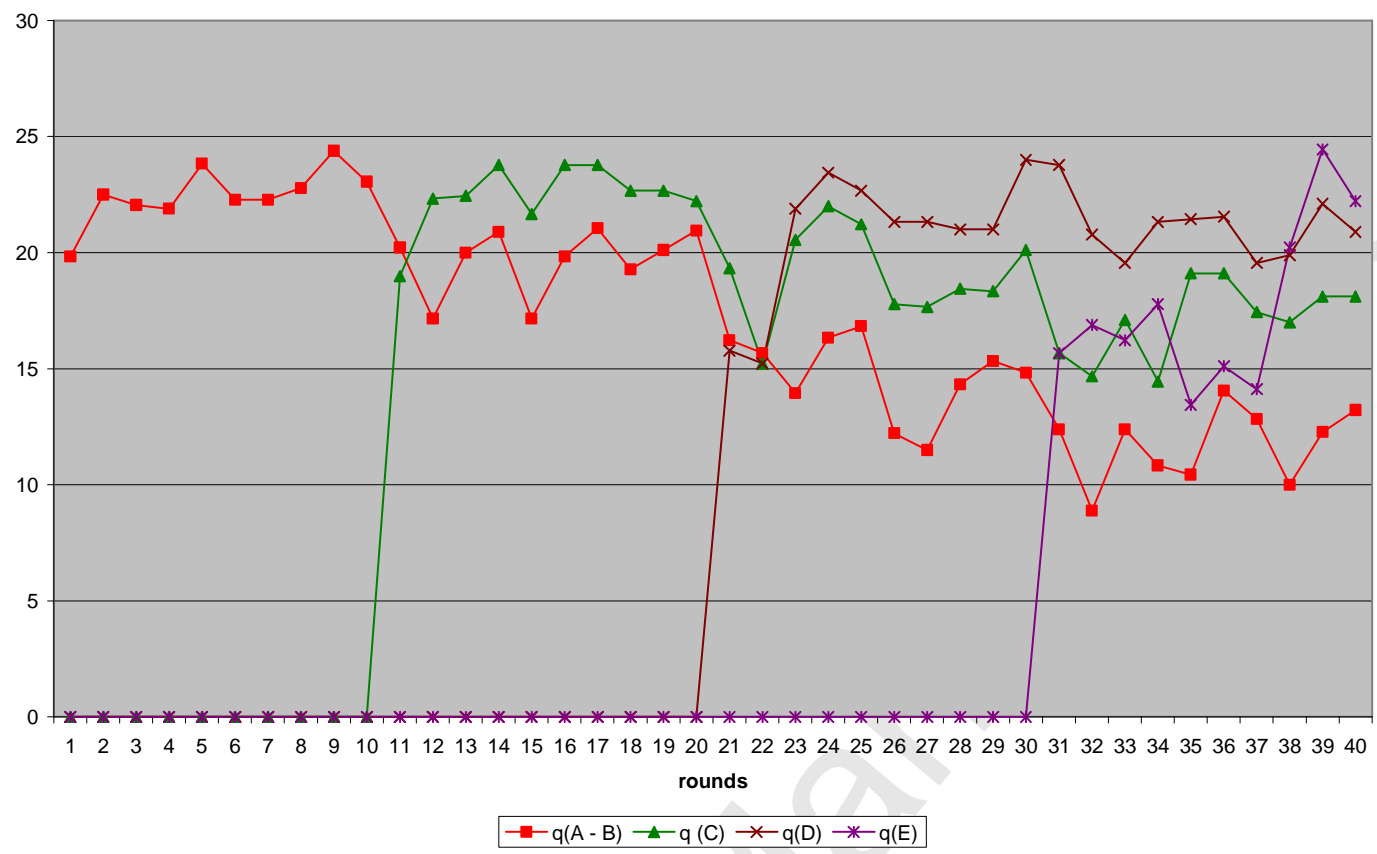

Figure 4: Average q (inefficient vs. efficient) and (actual vs. equ.) for Treatment Seq-Asym10

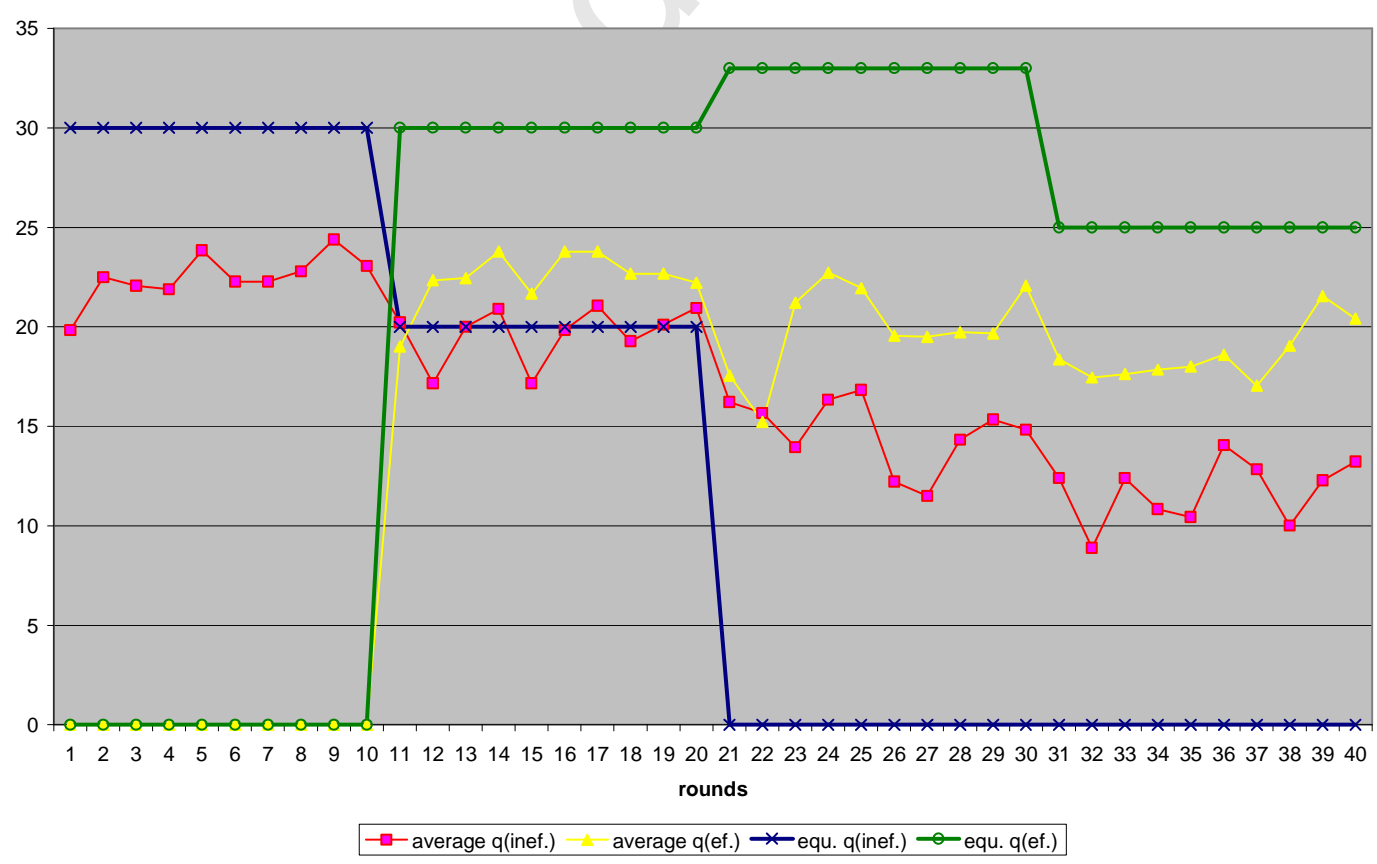


Figure 5: Average profit (inefficient vs efficient) for Treatment Seq-Asym10

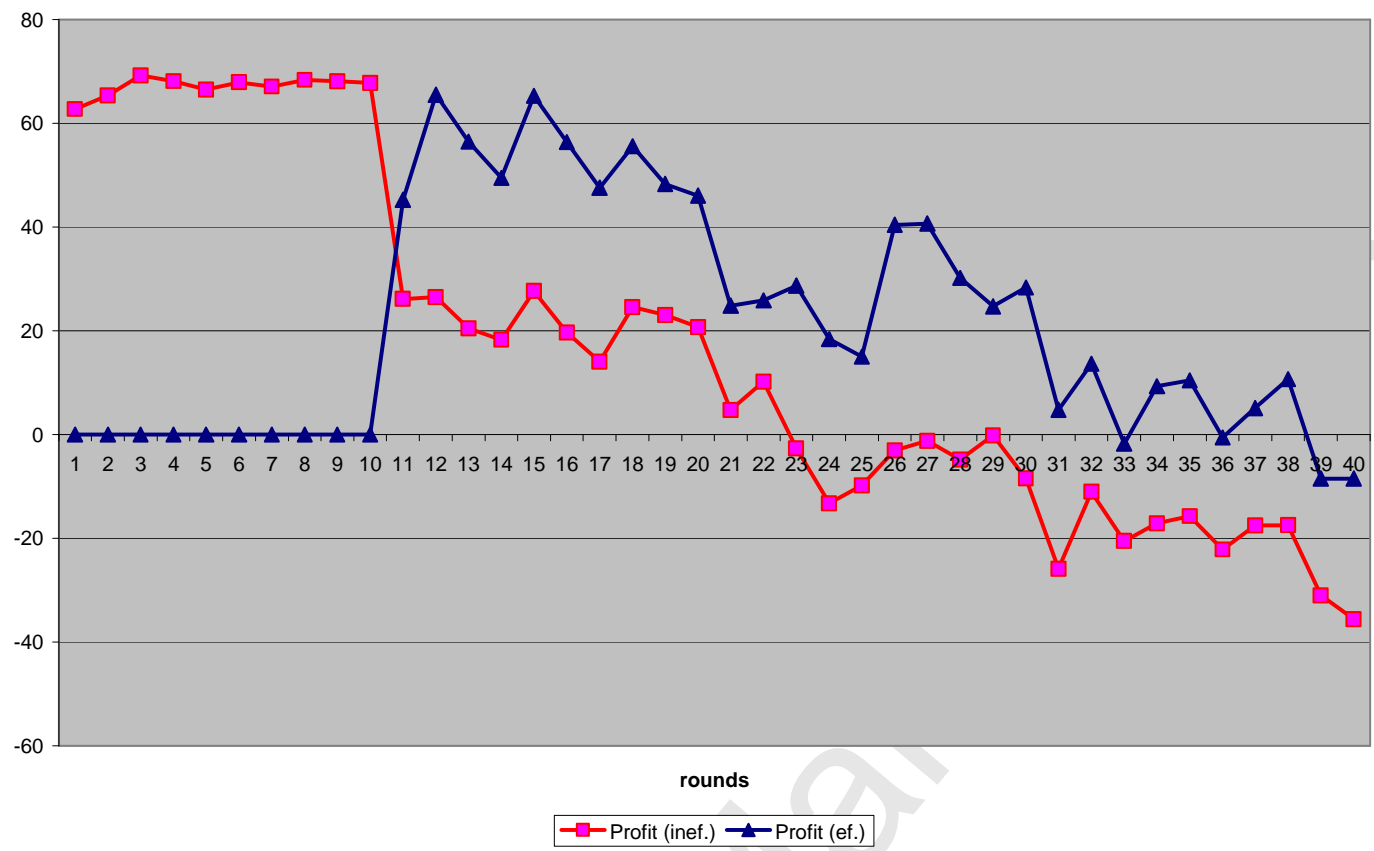

Figure 6: Average q (inefficient vs. efficient) and (actual vs equ) for Treatment Simul-Asym10

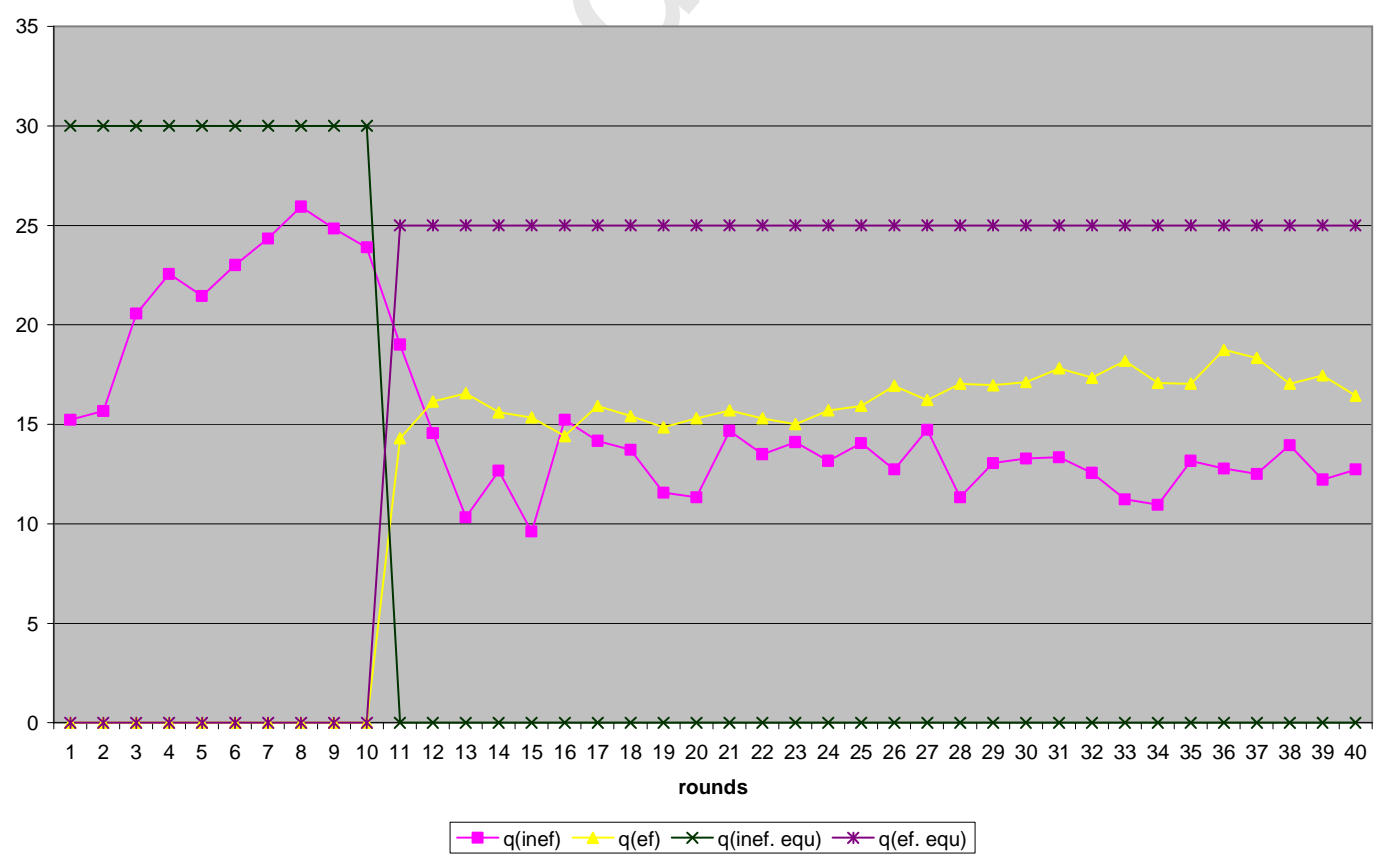


Figure 7: Average Profit (inefficient vs efficient) for Treatment Simul-Asym10

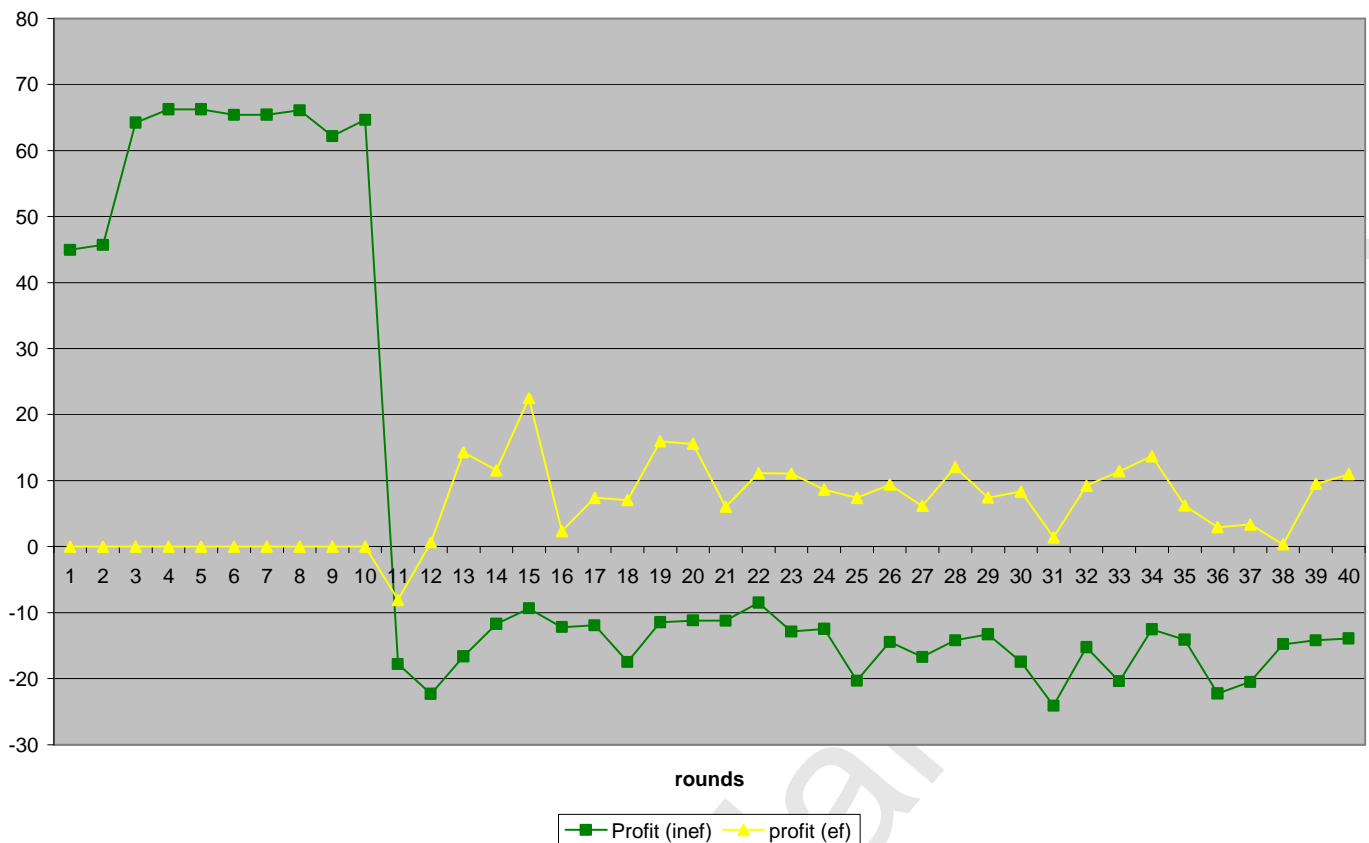

Figure 8: Average q across firm groups for Treatment Seq-Asym20

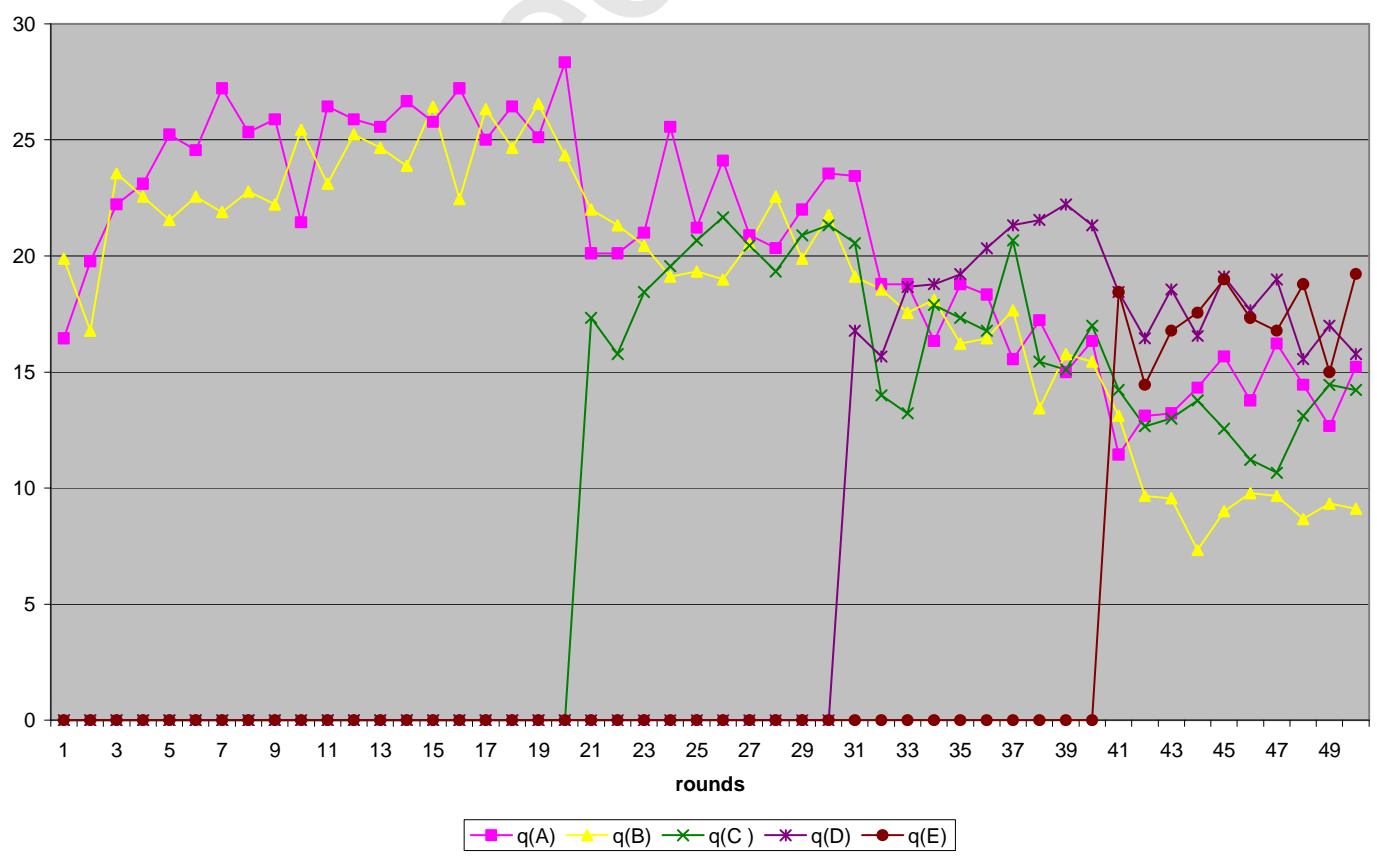


Figure 9: Average q(inefficient vs. efficient) and (actual vs. equ.) for Treatment Seq-Asym20

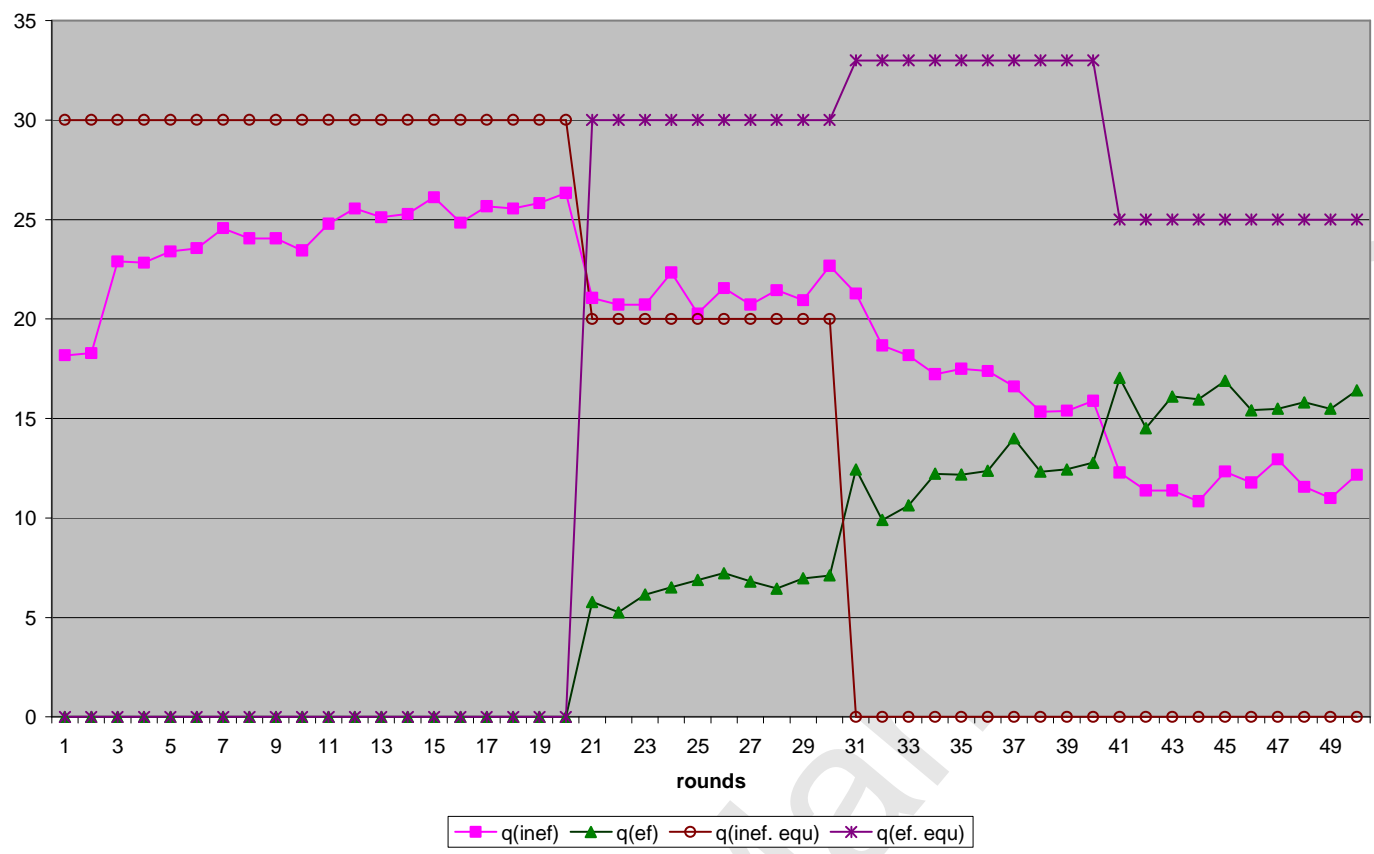

Figure 10: Average profits (inefficient vs. efficient) for Treatment Seq-Asym20

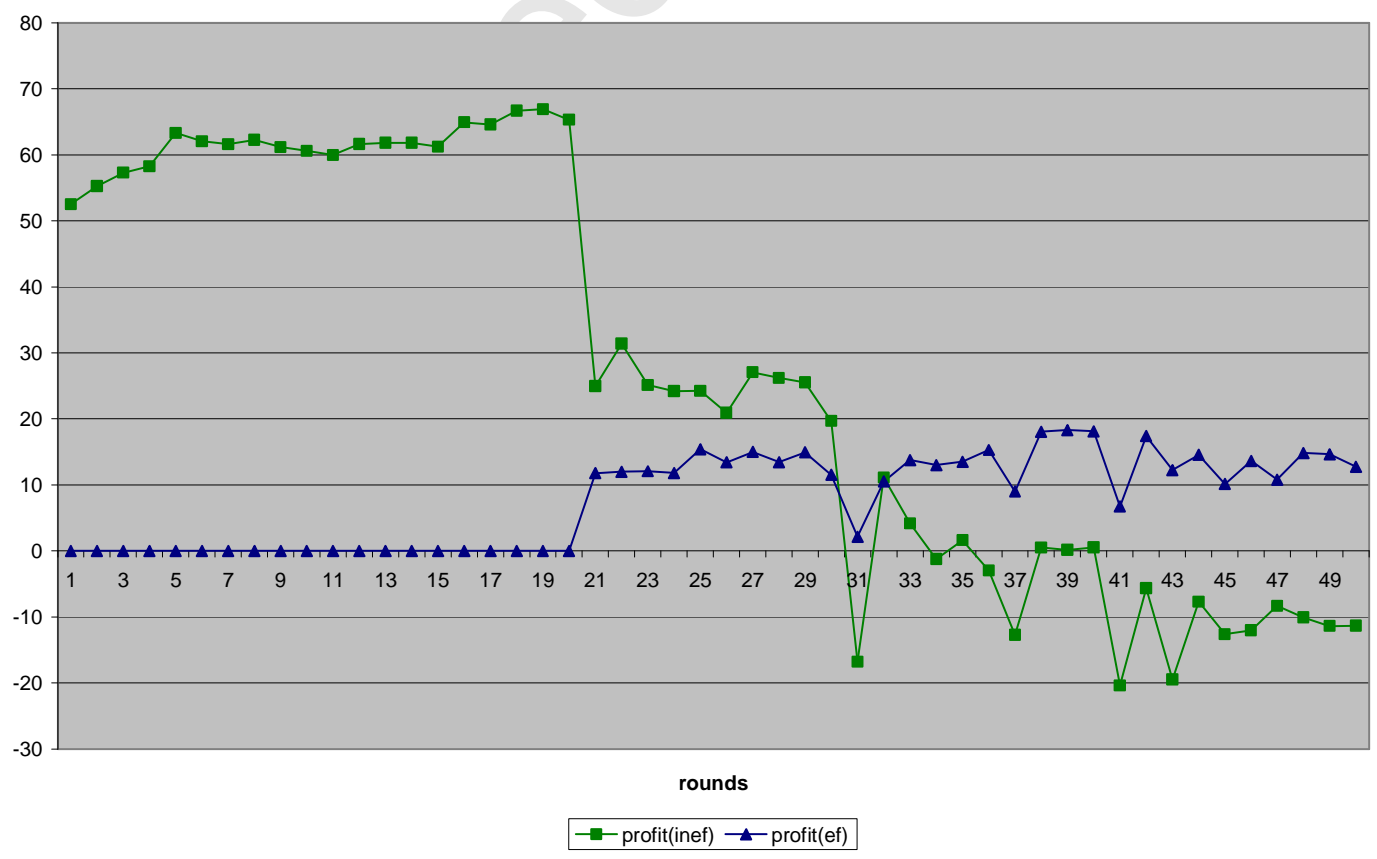


Figure 11: Average q (inefficient vs efficient) and (actual vs equ.) for Treatment Simul-Asym20

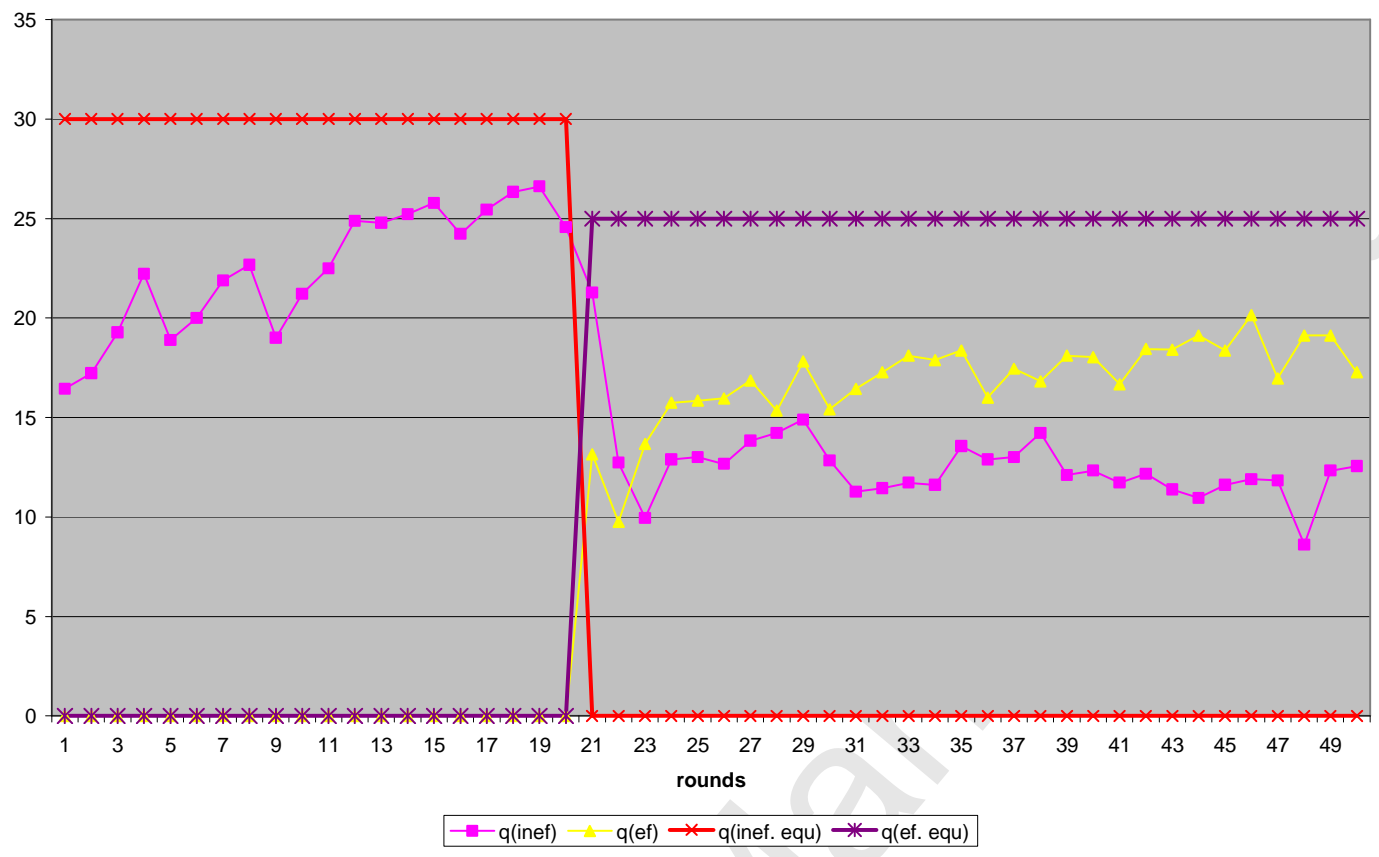

Figure 12: Average Profit (inefficient vs efficient) and (actual vs equ) for Treatment SimulAsym20

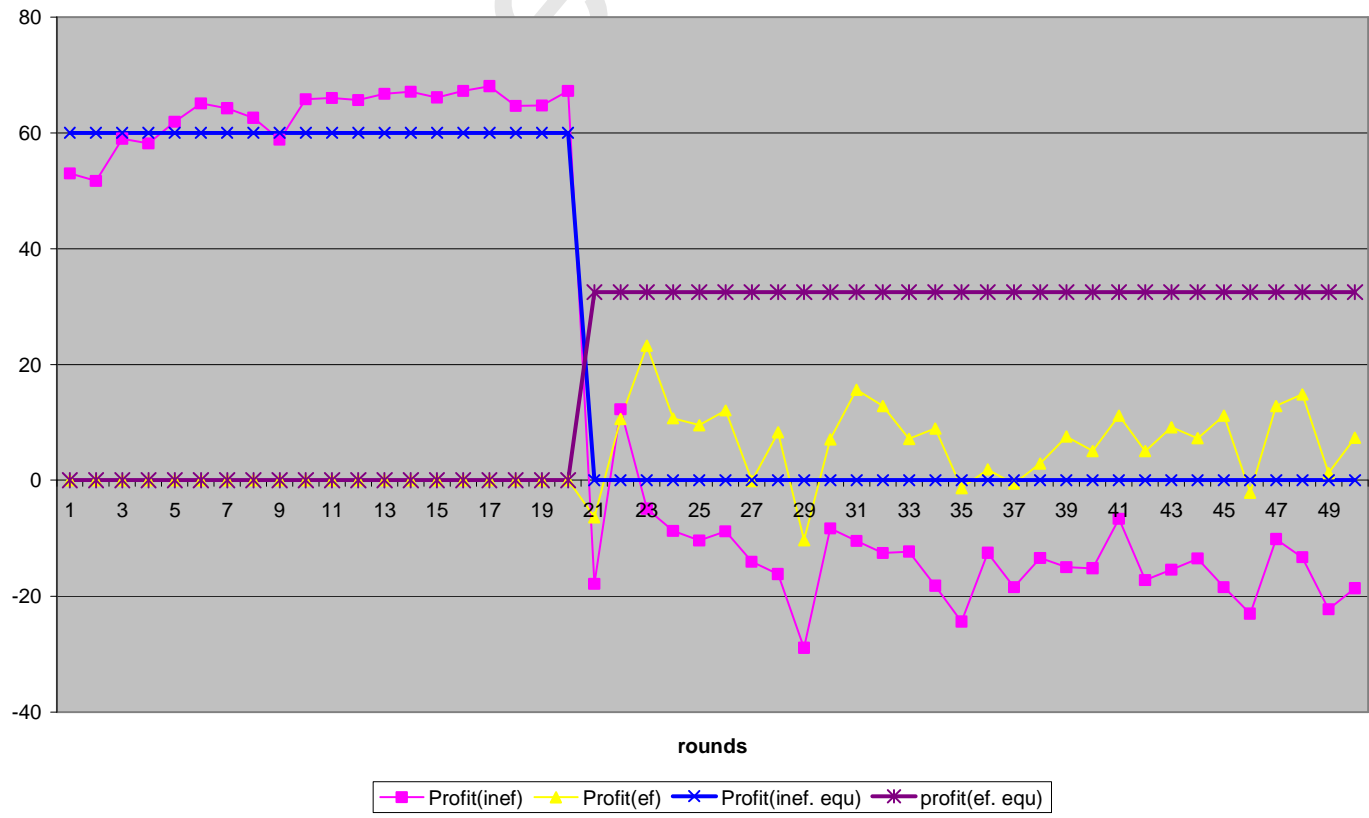


Figure 13: TP(actual)/ TP(equ) ratio across treatments

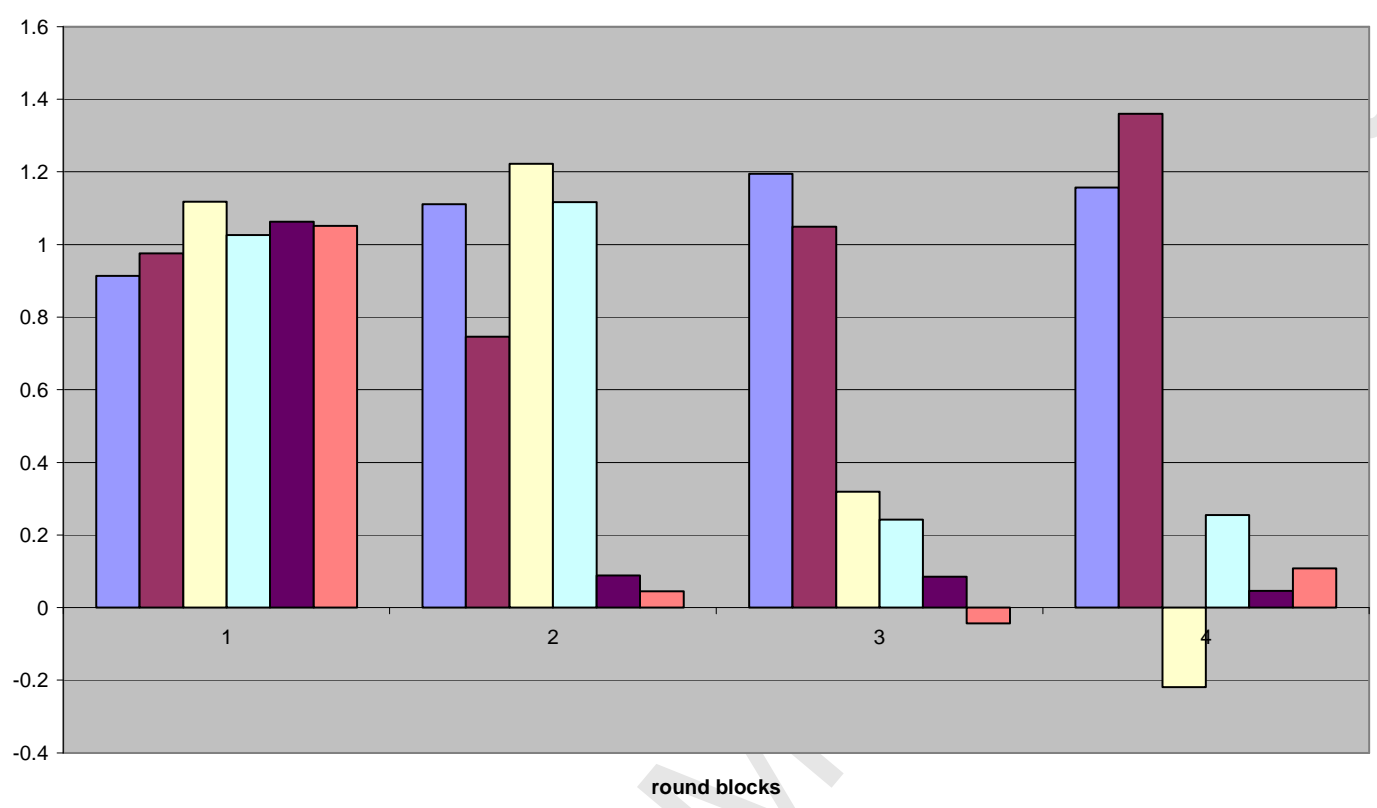

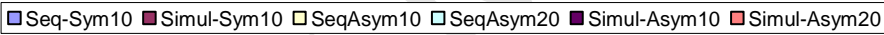

Figure 14: CS(actual) / CS(equ) ratio across treatments

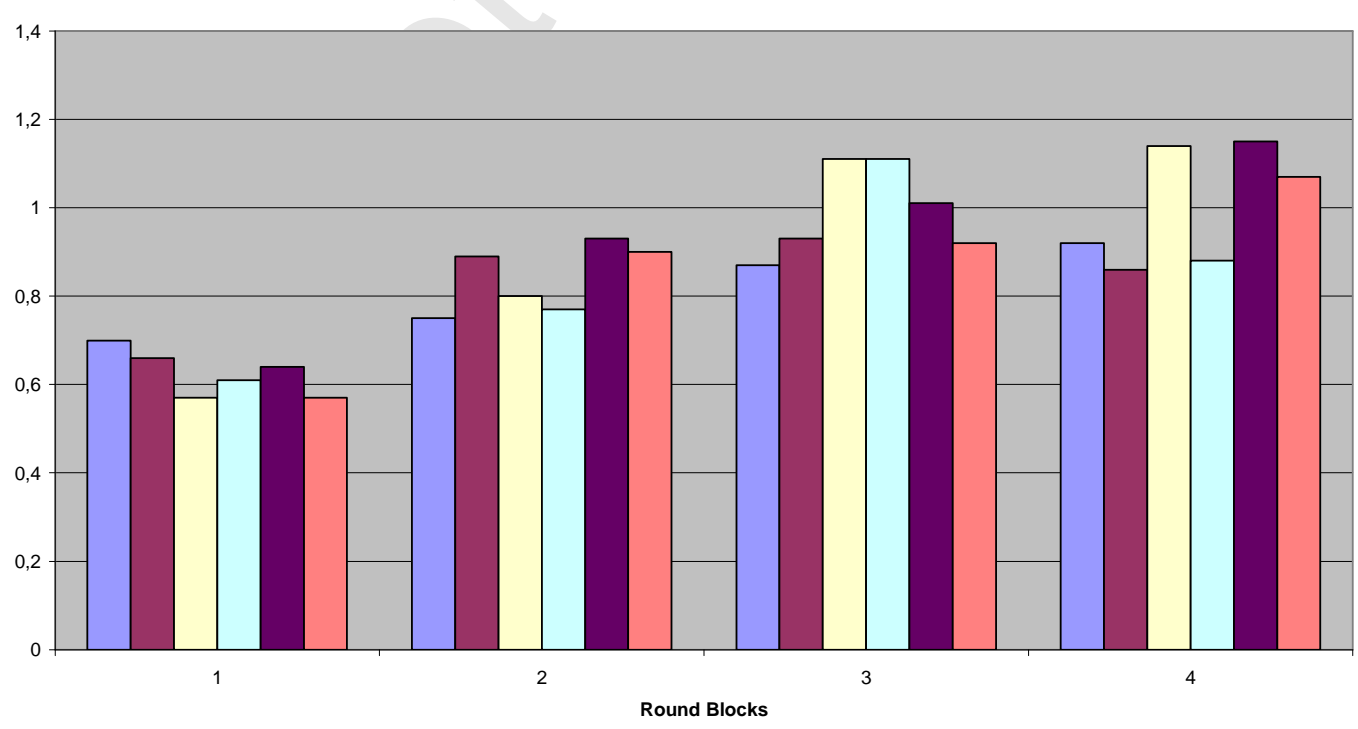

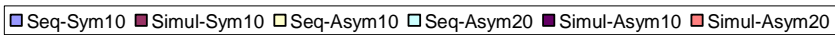




\section{APPENDIX: INSTRUCTIONS FOR TREATMENT 2.1a}

\section{General Information.}

We thank you for coming to the experiment. The purpose of this session is to study how people make decisions in a particular situation. During the session it will not be permitted to talk or communicate with the other participants. If you have a question, please raise your hand and one of us will come to your table to answer it. During the session you will earn money. During the session the income will be denominated in points. At the end of the session the points will be converted into euros in a way that is explained below.

At the end of the session the amount you have earned will be paid to you in cash. Payments are confidential, we will not inform any of the other participants of the amount that you earn.

Groups and types in groups.

During the experiment you will be in a group of five, you and another four participants. Each group will be composed by the same five persons during the whole experiment. The members of each group will be of different types: A, B, C, D and E. Types A and B will be in one situation, type C will be in a different situation, type $\mathrm{D}$ in a different situation, and type $\mathrm{E}$ in again a different situation. The composition of the groups and the types within the groups will be determined randomly.

Periods.

The session consists of 40 periods. In periods 1 to 10 the types A and B of each group will make decisions and the types $\mathrm{C}, \mathrm{D}$ and $\mathrm{E}$ will not make decisions. After each of the periods 1 to 10 all the types in one group will receive information about the decisions made by the A and B in the group.

In periods 11 to 20 types $\mathrm{A}, \mathrm{B}$ and $\mathrm{C}$ of each group will make decisions and types $\mathrm{D}$ and $\mathrm{E}$ will not make decisions. After each of the periods 11 to 20 all the types in one group will receive information about the decisions made by the $\mathrm{A}, \mathrm{B}$ and $\mathrm{C}$ in the group.

In periods 21 to 30 types $\mathrm{A}, \mathrm{B}, \mathrm{C}$ and $\mathrm{D}$ of each group will make decisions and type $\mathrm{E}$ will not make decisions. After each of the periods 21 to 30 all the types in one group will receive information about the decisions made by the $\mathrm{A}, \mathrm{B}, \mathrm{C}$ and $\mathrm{D}$ in the group.

In periods 31 to 40 types $\mathrm{A}, \mathrm{B}, \mathrm{C}, \mathrm{D}$ and $\mathrm{E}$ of each group all will make decisions. After each of the periods 31 to 40 all the types in one group will receive information about the decisions made by the A, $\mathrm{B}, \mathrm{C}, \mathrm{D}$ and $\mathrm{E}$ in the group. Period 40 will be the last of the session.

\begin{tabular}{ccc}
\hline & Decisions and periods \\
\hline Periods & Types that make decisions & $\begin{array}{c}\text { Types that don't make } \\
\text { decisions }\end{array}$ \\
\hline $1-10$ & A y B & C, D y E \\
$11-20$ & A, B y C & D y E \\
$21-30$ & A, B, C y D & E \\
$31-40$ & A, B, C, D y E & - \\
\hline
\end{tabular}

Decisions and earnings.

When somebody has the possibility of making a decision, this decision will consist in which quantity to produce to sell in a market. Any integer quantity between 0 and 30 can be chosen.

In periods 1 to 10 , types $\mathrm{A}$ and $\mathrm{B}$ of each group will have to decide individually which quantity to produce. Participants C, D and E will not make decisions and their earnings in these periods will be zero. 
The earnings of each period for A and B will depend on their decisions. If type A or B produces zero in a period his earnings in that period will be zero. If he produces a positive quantity then the earnings will be

Earnings $=($ Price $-\mathrm{MC}) *$ quantity produced by the participant $-\mathrm{F}$,

MC $=2$. This is called "marginal cost" and is paid for each produced unit.

$\mathrm{F}=30$. This is called "fixed cost". It is a fixed quantity which will be subtracted any time that the quantity produced by the participant is positive.

\begin{tabular}{|c|c|c|c|c|c|}
\hline $\begin{array}{c}\text { TOTAL } \\
\text { QUANTITY } \\
\text { PRODUCED }\end{array}$ & PRICE & $\begin{array}{c}\text { TOTAL } \\
\text { QUANTITY } \\
\text { PRODUCED }\end{array}$ & PRICE & $\begin{array}{c}\text { TOTAL } \\
\text { QUANTITY } \\
\text { PRODUCED }\end{array}$ & PRICE \\
\hline & & & & 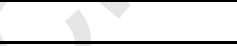 & \\
\hline 1 & 10.9 & 41 & 6.9 & 81 & 2.9 \\
\hline 2 & 10.8 & 42 & 6.8 & 82 & 2.8 \\
\hline 3 & 10.7 & 43 & 6.7 & 83 & 2.7 \\
\hline 4 & 10.6 & 44 & 6.6 & 84 & 2.6 \\
\hline 5 & 10.5 & 45 & 6.5 & 85 & 2.5 \\
\hline 6 & 10.4 & 46 & 6.4 & 86 & 2.4 \\
\hline 7 & 10.3 & 47 & 6.3 & 87 & 2.3 \\
\hline 8 & 10.2 & 48 & 6.2 & 88 & 2.2 \\
\hline 9 & 10.1 & 49 & 6.1 & 89 & 2.1 \\
\hline 10 & 10 & 50 & 6 & 90 & 2 \\
\hline 11 & 9.9 & 51 & 5.9 & 91 & 1.9 \\
\hline 12 & 9.8 & 52 & 5.8 & 92 & 1.8 \\
\hline 13 & 9.7 & 53 & 5.7 & 93 & 1.7 \\
\hline 14 & 9.6 & 54 & 5.6 & 94 & 1.6 \\
\hline 15 & 9.5 & 55 & 5.5 & 95 & 1.5 \\
\hline 16 & 9.4 & 56 & 5.4 & 96 & 1.4 \\
\hline 17 & 9.3 & 57 & 5.3 & 97 & 1.3 \\
\hline 18 & 9.2 & 58 & 5.2 & 98 & 1.2 \\
\hline 19 & 9.1 & 59 & 5.1 & 99 & 1.1 \\
\hline 20 & 9 & 60 & 5 & 100 & 1 \\
\hline 21 & 8.9 & 61 & 4.9 & 101 & 0.9 \\
\hline 22 & 8.8 & 62 & 4.8 & 102 & 0.8 \\
\hline 23 & 8.7 & 63 & 4.7 & 103 & 0.7 \\
\hline 24 & 8.6 & 64 & 4.6 & 104 & 0.6 \\
\hline 25 & 8.5 & 65 & 4.5 & 105 & 0.5 \\
\hline 26 & 8.4 & 66 & 4.4 & 106 & 0.4 \\
\hline 27 & 8.3 & 67 & 4.3 & 107 & 0.3 \\
\hline 28 & 8.2 & 68 & 4.2 & 108 & 0.2 \\
\hline 29 & 8.1 & 69 & 4.1 & 109 & 0.1 \\
\hline 30 & 8 & 70 & 4 & 110 & 0 \\
\hline 31 & 7.9 & 71 & 3.9 & 111 & -0.1 \\
\hline 32 & 7.8 & 72 & 3.8 & 112 & -0.2 \\
\hline 33 & 7.7 & 73 & 3.7 & 113 & -0.3 \\
\hline 34 & 7.6 & 74 & 3.6 & 114 & -0.4 \\
\hline 35 & 7.5 & 75 & 3.5 & 115 & -0.5 \\
\hline 36 & 7.4 & 76 & 3.4 & 116 & -0.6 \\
\hline 37 & 7.3 & 77 & 3.3 & 117 & -0.7 \\
\hline 38 & 7.2 & 78 & 3.2 & 118 & -0.8 \\
\hline 39 & 7.1 & 79 & 3.1 & 119 & -0.9 \\
\hline 40 & 7 & 80 & 3 & 120 & -1 \\
\hline
\end{tabular}


The price depends on the sum of the quantities produced by types A and B. To see what prices correspond to the different sums of quantities see the table on the next page. Observe that the larger the sum of quantities produced by A and B the lower the price. If the resulting price is very low or negative the earnings from the period can be negative

In periods 11 to 20 , types $\mathrm{A}, \mathrm{B}$ and $\mathrm{C}$ of each group will have to decide individually which quantity to produce. Participants D and E will not make decisions and their earnings in these periods will be zero.

The earnings of each period for $\mathrm{A}, \mathrm{B}$ and $\mathrm{C}$ will depend on their decisions. If type $\mathrm{A}, \mathrm{B}$ or $\mathrm{C}$ produces zero in a period his earnings in that period will be zero. If he produces a positive quantity then the earnings will be:

Earnings $=($ Price $-\mathrm{MC}) *$ quantity produced by the participant $-\mathrm{F}$,

MC $=2$. This is called "marginal cost" and is paid for each produced unit.

with $\mathrm{MC}=2$ and $\mathrm{F}=30$ as before for types $\mathrm{A}$ and $\mathrm{B}$, and $\mathrm{MC}=1$ and $\mathrm{F}=30$ for type $\mathrm{C}$.

The price now depends on the sum of the quantities produced by types A, B and C, following the same table as before. If the resulting price is very low or negative the earnings from the period can be negative.

In periods 21 to 30 , types $\mathrm{A}, \mathrm{B}, \mathrm{C}$ and $\mathrm{D}$ of each group will have to decide individually which quantity to produce. Participant E will not make decisions and his earnings in these periods will be zero. The earnings of each period for A, B, C and D will be determined by the same expression as before, with $\mathrm{MC}=1$ and $\mathrm{F}=30$ for type $\mathrm{D}$.

The price now depends on the sum of the quantities produced by types A, B, C and D following the same table as before. If the resulting price is very low or negative the earnings from the period can be negative.

In periods 31 to 40, types A, B, C, D and E of each group will have to decide individually which quantity to produce. The earnings of each period for $\mathrm{A}, \mathrm{B}, \mathrm{C}, \mathrm{D}$ and $\mathrm{E}$ will be determined by the same expression as before, with $\mathrm{MC}=1$ and $\mathrm{F}=30$ for type $\mathrm{E}$.

The price now depends on the sum of the quantities produced by types A, B, C, D and E following the same table as before. If the resulting price is very low or negative the earnings from the period can be negative.

Information after each period.

After each period you will all be informed of the total quantity produced by the group, of your own production and (in case it applies) of your earnings in points. You will also be informed of your accumulated earnings.

\section{Types and identification numbers}

On your screen you will see your identication number.

The participants with identification numbers 1, 6, and 11 will be the types A of each of the groups. The participants with identification numbers 2, 7, and 12 will be the types B of each of the groups. The participants with identification numbers 3,8 , and 13 will be the types $C$ of each of the groups. The participants with identification numbers 4,9 , and 14 will be the types $\mathrm{D}$ of each of the groups. The participants with identification numbers 5, 10, and 15 will be the types $\mathrm{E}$ of each of the groups.

Total earnings.

At the beginning of the session each participant will receive and additional endowment of 330 points. After each period the earnings of the period will be added to (or subtracted from) the initial endowment to determine the current earnings in points.

At the end of the session the earnings in points will be transformed into euros. The exchange rate will be different for each type.

For types A and B each point will be exchanged for 0,021 euros.

For type $\mathrm{C}$ each point will be exchanged for 0,019 euros.

For type $\mathrm{D}$ each point will be exchanged for 0,029 euros.

For type E each point will be exchanged for 0,075. euros. 